\title{
Multi-model mean nitrogen and sulfur deposition from the Atmospheric Chemistry and Climate Model Intercomparison Project (ACCMIP): evaluation of historical and projected future changes
}

\author{
J.-F. Lamarque ${ }^{1}$, F. Dentener ${ }^{2}$, J. McConnell ${ }^{3}$, C.-U. Ro ${ }^{4}$, M. Shaw ${ }^{4}$, R. Vet $^{4}$, D. Bergmann ${ }^{5}$, P. Cameron-Smith ${ }^{5}$, \\ S. Dalsoren ${ }^{6}$, R. Doherty ${ }^{7}$, G. Faluvegi ${ }^{8}$, S. J. Ghan ${ }^{9}$, B. Josse ${ }^{10}$, Y. H. Lee ${ }^{8}$, I. A. MacKenzie ${ }^{7}$, D. Plummer ${ }^{11}$, \\ D. T. Shindell ${ }^{8}$, R. B. Skeie ${ }^{6}$, D. S. Stevenson ${ }^{7}$, S. Strode ${ }^{12,13}$, G. Zeng ${ }^{14}$, M. Curran ${ }^{15}$, D. Dahl-Jensen ${ }^{16}$, S. Das ${ }^{17}$, \\ D. Fritzsche ${ }^{18}$, and M. Nolan ${ }^{19}$ \\ ${ }^{1}$ NCAR Earth System Laboratory, National Center for Atmospheric Research, Boulder, CO, USA \\ ${ }^{2}$ European Commission, Joint Research Centre, Ispra, Italy \\ ${ }^{3}$ Desert Research Institute, Reno, NV, USA \\ ${ }^{4}$ Environment Canada, Toronto, Ontario, Canada \\ ${ }^{5}$ Lawrence Livermore National Laboratory, Livermore, CA, USA \\ ${ }^{6}$ Center for International Climate and Environmental Research-Oslo (CICERO), Oslo, Norway \\ ${ }^{7}$ School of GeoSciences, University of Edinburgh, Edinburgh, UK \\ ${ }^{8}$ NASA Goddard Institute for Space Studies and Columbia Earth Institute, New York, NY, USA \\ ${ }^{9}$ Pacific Northwest National Laboratory, Richland, WA, USA \\ ${ }^{10}$ GAME/CNRM, Météo-France, CNRS - Centre National de Recherches Météorologiques, Toulouse, France \\ ${ }^{11}$ Canadian Centre for Climate Modeling and Analysis, Environment Canada, Victoria, British Columbia, Canada \\ ${ }^{12}$ NASA Goddard Space Flight Center, Greenbelt, MD, USA \\ ${ }^{13}$ Universities Space Research Association, Columbia, MD, USA \\ ${ }^{14}$ National Institute of Water and Atmospheric Research, Lauder, New Zealand \\ ${ }^{15}$ Australian Antarctic Division and Antarctic Climate \& Ecosystems CRC, Hobart, Tasmania, Australia \\ ${ }^{16}$ Niels Bohr Institute, University of Copenhagen, Copenhagen, Denmark \\ ${ }^{17}$ Woods Hole Oceanographic Institution, Woods Hole, MA, USA \\ ${ }^{18}$ Alfred Wegener Institute, Helmholtz Centre for Polar and Marine Research, Research Unit Potsdam, Potsdam, Germany \\ ${ }^{19}$ University of Alaska Fairbanks, Fairbanks, AK, USA
}

Correspondence to: J.-F. Lamarque (lamar@ucar.edu)

Received: 31 January 2013 - Published in Atmos. Chem. Phys. Discuss.: 8 March 2013

Revised: 21 June 2013 - Accepted: 24 June 2013 - Published: 20 August 2013

\begin{abstract}
We present multi-model global datasets of nitrogen and sulfate deposition covering time periods from 1850 to 2100, calculated within the Atmospheric Chemistry and Climate Model Intercomparison Project (ACCMIP). The computed deposition fluxes are compared to surface wet deposition and ice core measurements. We use a new dataset of wet deposition for 2000-2002 based on critical assessment of the quality of existing regional network data. We show that for present day (year 2000 ACCMIP time slice), the
\end{abstract}

ACCMIP results perform similarly to previously published multi-model assessments. For this time slice, we find a multimodel mean deposition of approximately $50 \mathrm{Tg}(\mathrm{N}) \mathrm{yr}^{-1}$ from nitrogen oxide emissions, $60 \mathrm{Tg}(\mathrm{N}) \mathrm{yr}^{-1}$ from ammonia emissions, and $83 \mathrm{Tg}(\mathrm{S}) \mathrm{yr}^{-1}$ from sulfur emissions. The analysis of changes between 1980 and 2000 indicates significant differences between model and measurements over the United States but less so over Europe. This difference points towards a potential misrepresentation of $1980 \mathrm{NH}_{3}$

Published by Copernicus Publications on behalf of the European Geosciences Union. 
emissions over North America. Based on ice core records, the 1850 deposition fluxes agree well with Greenland ice cores, but the change between 1850 and 2000 seems to be overestimated in the Northern Hemisphere for both nitrogen and sulfur species. Using the Representative Concentration Pathways (RCPs) to define the projected climate and atmospheric chemistry related emissions and concentrations, we find large regional nitrogen deposition increases in 2100 in Latin America, Africa and parts of Asia under some of the scenarios considered. Increases in South Asia are especially large, and are seen in all scenarios, with 2100 values more than double their 2000 counterpart in some scenarios and reaching $>1300 \mathrm{mg}(\mathrm{N}) \mathrm{m}^{-2} \mathrm{yr}^{-1}$ averaged over regional to continental-scale regions in RCP 2.6 and 8.5, 30-50\% larger than the values in any region currently (circa 2000). However, sulfur deposition rates in 2100 are in all regions lower than in 2000 in all the RCPs. The new ACCMIP multimodel deposition dataset provides state-of-the-science, consistent and evaluated time slice (spanning 1850-2100) global gridded deposition fields for use in a wide range of climate and ecological studies.

\section{Introduction}

The global nitrogen cycle is of importance for a number of key issues, such as ecology and biodiversity (e.g., Phoenix et al., 2006; Bobbink et al., 2010; Butchart et al., 2010), eutrophication and acidification (e.g., Bouwman et al., 2002; Rodhe et al., 2002; Fisher et al., 2011), climate changecarbon cycle interactions (e.g., Thornton et al., 2007; Reay et al., 2008; Zaehle et al. 2010), food and energy production (Sutton et al., 2011). Nitrogen emissions also impact human health through particulate matter and ozone formation. Clearly, nitrogen is central to many aspects of life on earth (Galloway et al., 2008; Fowler et al., 2013). Similarly, sulfur is an essential nutrient, but excessive sulfur deposition has been linked to a decrease in tree growth as a result of soil acidification and modification to plant nutrition and soil chemistry (Savva and Berninger, 2010).

Dinitrogen $\left(\mathrm{N}_{2}\right)$ is the most abundant component in the atmosphere, but is chemically unreactive. More reactive atmospheric nitrogen components include oxidized $\mathrm{NO}_{\mathrm{y}}(=\mathrm{NO}+$ $\mathrm{NO}_{2}+$ other minor inorganic components and organic nitrogens), the long-lived greenhouse gas nitrous oxide $\left(\mathrm{N}_{2} \mathrm{O}\right.$, with a lifetime of $131 \pm 10 \mathrm{yr}$, Prather et al., 2012), and reduced nitrogen $\mathrm{NH}_{\mathrm{x}}\left(=\mathrm{NH}_{3}+\mathrm{NH}_{4}^{+}\right)$as well as organic nitrogen components such as amines (Kanakidou et al., 2012) and organic nitrates. Deposited $\mathrm{SO}_{\mathrm{x}}\left(=\mathrm{SO}_{2}+\mathrm{SO}_{4}^{2-}\right)$ sulfur compounds originate from emissions of $\mathrm{SO}_{2}$, sulfate and dimethyl sulfide.

Anthropogenic emissions of $\mathrm{NO}_{\mathrm{y}}, \mathrm{NH}_{\mathrm{x}}$ and $\mathrm{SO}_{\mathrm{x}}$ components are estimated to have increased by a factor of 5 to 10 since 1850 (van Aardenne et al., 2001; Lamarque et al.,
2010). Knowledge of the link between their generation by human activities and subsequent transformations and impacts requires an accurate description of large-scale emissions, atmospheric chemistry, transport and removal, all of which occur on relatively fast timescales (up to a few weeks) compared to nitrogen in the other compartments of relevance to the earth system: terrestrial, coastal zones and open ocean.

Global atmospheric chemistry-transport models are routinely used as a tool to calculate the global dispersion of $\mathrm{NO}_{\mathrm{y}}$, $\mathrm{NH}_{\mathrm{x}}$ and $\mathrm{SO}_{\mathrm{x}}$. Since individual models are prone to specific errors and multi-model means typically outperform individual models (e.g., Reichler and Kim, 2008; Shindell et al., 2013), it has become common to use model ensemble calculations to improve the quality of the calculations. Previous deposition ensemble studies include Lamarque et al. (2005) using 6 models and focusing on $\mathrm{NO}_{\mathrm{y}}$ deposition, Dentener et al. (2006) using 23 models and discussing $\mathrm{NO}_{\mathrm{y}}, \mathrm{NH}_{\mathrm{x}}$ and $\mathrm{SO}_{\mathrm{x}}$ deposition under current and 2 future scenarios, and Sanderson et al. (2008) using 15 models and focusing on export of $\mathrm{NO}_{\mathrm{y}}$ and subsequent deposition.

The present study uses deposition fields generated by 11 models that participated in the Atmospheric Chemistry and Climate Model Intercomparison Project (ACCMIP; Lamarque et al., 2013). ACCMIP was designed to inform aspects of the forthcoming Intergovernmental Panel on Climate Change Fifth Assessment Report regarding the role of longterm changes in atmospheric chemistry on climate and vice versa. In this ACCMIP study simulations were provided for time slices representative of the period around 1850, 1980, 2000, 2030 and 2100 (see Sect. 2), where the future atmospheric chemistry-climate conditions follow the 4 Representative Concentration Pathways (RCPs, Moss et al., 2010). Because of the importance of sulfur deposition (in association with nitrogen deposition) for the understanding of soil and water acidification (Fisher et al., 2011), we have included an analysis of sulfur deposition to the more traditional nitrogen deposition analysis. The models used in this analysis represent a combination of the current generation of chemistrytransport models and chemistry-climate models, with somewhat refined horizontal (ranging from $1.875 \times 2.5$ degrees to $5 \times 5$ degrees) and vertical resolution (from 19 to 72 levels) and more detailed descriptions of chemical processes compared to previous studies (namely the results discussed in Dentener et al., 2006; Sanderson et al., 2008). Rather than representing specific meteorological years - as in these previous studies - each model meteorology (generated by climate models) is representative in a climatic sense of the decade under consideration (e.g., 1850-1859; or 2000-2009) and hence includes the effect of climate change.

This paper is structured as follows. Section 2 gives a short description of the models and the ACCMIP experiments. We also define there the methodology for computing the multimodel mean (MMM). Section 3 describes the measurement datasets used in this paper, from surface sites and from ice cores. In Sect. 4, we evaluate the multi-model mean for the 
2000 period - when extensive measured deposition datasets are available, and which also allows us to make a retrospective analysis of the quality of data in this model dataset compared to the earlier and widely used Photocomp (Dentener et al., 2006) and HTAP (Sanderson et al., 2008; Vet et al., 2013) deposition datasets. In Sect. 5, a more limited analysis is given for the changes in deposition (and its drivers) since the 1980s. In Sect. 6, using ice cores, we evaluate the simulated change between decades centered around 1850 and 2000. The 1980-2000 period is of particular interest since, due to implementation of national and international emission control measures, strong emission reductions have been reported, especially over North America and Europe, with commensurate consequences for deposition. Section 7 describes the overall global structure of total deposition (dry and wet) from 1850 to 2100 . A discussion and conclusions follow in Sect. 8.

\section{ACCMIP simulations and multi-model mean}

An overview of the Atmospheric Chemistry and Climate Model Intercomparison Project simulations and participating models is given in Lamarque et al. (2013). Consequently, we focus here on the aspects relevant to the analysis of nitrogen and sulfate deposition.

ACCMIP provides an analysis of the role of atmospheric chemistry changes in the near-term (up to 2100) climate forcing included in the CMIP5 (Climate Model Intercomparison Project Phase 5; Taylor et al., 2012) simulations, including the chemical composition changes associated with the CMIP5 prescribed forcings. The ACCMIP simulations used in the present study (Table 1) consist of time slice experiments (for specific periods spanning 1850 to 2100 with a minimum increment of $10 \mathrm{yr}$ ) with chemistry diagnostics. Each requested simulation is labeled as primary ("P") or optional ("O"). Although simulations using the Representative Concentration Pathway 6.0 (RCP6.0, Masui et al., 2011) emissions were performed, not enough groups provided the necessary fields for a meaningful analysis of nitrogen and sulfur depositions; therefore, this work focuses on the remaining three RCP projections RCP2.6, RCP4.5 and RCP8.5 (see van Vuuren et al., 2011, and references therein). A primary output of these simulations was nitrogen and sulfate (dry and wet) deposition fields (see Table $\mathrm{S} 1$ in Lamarque et al., 2013). Although the ACCMIP models were required to specify the anthropogenic and biomass burning emissions according to Lamarque et al. (2010) for 1850-2000 and the RCP emissions (van Vuuren et al., 2011) beyond 2000, there is a range of emissions that were used in ACCMIP models, mostly from variations in the treatment of natural emissions (Lamarque et al., 2013; Young et al., 2013).

As a first step in the quality control of the model calculated depositions, we analyze for each model the balance between emission and deposition as reported by the mod-
Table 1. List and principal characteristics of ACCMIP simulations ( $\mathrm{P}$ indicates the primary simulations, $\mathrm{O}$ the optional ones). SSTs stands for sea surface temperatures and GHGs for greenhouse gases. Adapted from Lamarque et al. (2013).

\begin{tabular}{lcccc}
\hline Historical simulations & 1850 & 1930 & 1980 & 2000 \\
\hline $\begin{array}{l}\text { Emissions and SSTs/ } \\
\text { GHGs for given year }\end{array}$ & $\mathrm{P}$ & $\mathrm{P}$ & $\mathrm{P}$ & $\mathrm{P}$ \\
\hline Future simulations & 2010 & 2030 & 2050 & 2100 \\
\hline RCP 2.6 (emissions, GHGs and SSTs) & & $\mathrm{P}$ & $\mathrm{O}$ & $\mathrm{P}$ \\
RCP 4.5 (emissions, GHGs and SSTs) & $\mathrm{O}$ & $\mathrm{O}$ & $\mathrm{O}$ & $\mathrm{O}$ \\
RCP 6.0 (emissions, GHGs and SSTs) & $\mathrm{P}$ & $\mathrm{P}$ & $\mathrm{O}$ & $\mathrm{P}$ \\
RCP 8.5 (emissions, GHGs and SSTs) & & $\mathrm{P}$ & $\mathrm{O}$ & $\mathrm{P}$ \\
\hline
\end{tabular}

eling groups (Tables 2-4) for the year 2000 time slice experiment. This analysis is done separately for nitrogen originating from nitrogen oxide emissions (deposition fields are referred as a group as $\mathrm{NO}_{\mathrm{y}}$ ) or ammonia emissions $\left(\mathrm{NH}_{\mathrm{x}}\right)$ and sulfur emissions $\left(\mathrm{SO}_{\mathrm{x}}\right)$. We find that the $\mathrm{NO}_{\mathrm{y}}$ deposition is larger than the emissions (surface and upper air, including lightning) by approximately $1 \mathrm{Tg}(\mathrm{N}) \mathrm{yr}^{-1}$, representing the input of nitrogen (mostly in the form of nitric acid) from the stratosphere, in general agreement with observational estimates of $0.45 \mathrm{Tg}(\mathrm{N}) \mathrm{yr}^{-1}$ from Murphy and $\mathrm{Fa}$ hey (1998), except for the GISS model where this influx is approximately $5 \mathrm{Tg}(\mathrm{N}) \mathrm{yr}^{-1}$ and the CMAM and MOCAGE models where the balance between deposition and emission is achieved within round-off. In the case of ammonia, the balance between emissions and deposition is clearly attained. In the case of sulfur, this balance cannot be fully evaluated due to the lack of diagnostics on the formation of sulfate aerosols from the emitted dimethylsulfide (DMS). Boucher et al. (2003) estimated the yield (DMS to sulfate aerosols) to be $87 \%$ when both gas-phase and aqueous-phase reactions are taken into account, but this number will be somewhat model dependent. Within that limitation, we assume that balance between sulfur deposition and emission is achieved for the listed models.

The focus of this paper is on documenting the multi-model mean (MMM) generated for each time slice. The MMM is constructed by linearly interpolating the model-generated monthly fields (for example wet deposition combined for all $\mathrm{NO}_{\mathrm{y}}$ species) at their native horizontal resolution (Table $\mathrm{S} 1$ ) to a common $0.5^{\circ} \times 0.5^{\circ}$ grid (finer than any model grid), identical to the emission grid used in Lamarque et al. (2010). Then, each field is averaged across models at the original monthly temporal resolution to generate its multi-model mean and standard deviation (Tables S2-S4). As indicated in these tables, the largest number of models (up to 10) that generated the necessary fields was for the historical $\mathrm{NO}_{\mathrm{y}}$ deposition (Table S5), followed by the RCP8.5 simulations. The number of models performing ammonium chemistry and deposition is however much smaller (2-5 models, depending on the simulated time period) while between 2 and 7 models 
Table 2. Summary of global totals $\left(\mathrm{Tg}(\mathrm{N}) \mathrm{yr}^{-1}\right)$ for deposition and emissions in 2000 related to the nitrogen oxide emissions. "Total dep." (4th column) is the sum of wet and dry deposition, while "Total emi." (7th column) is the sum of $\mathrm{NO}_{\mathrm{x}}$ surface and aircraft emissions (eminox) and lightning emissions (emilnox). Note that deposition is equal or slightly larger than emissions due to the net input of nitrogen (usually in the form of nitric acid) from the stratosphere (approximately $\left.1 \mathrm{Tg}^{\mathrm{N}} \mathrm{N}\right) \mathrm{yr}^{-1}$, except for the GISS models which have a $5 \mathrm{Tg}^{-\mathrm{N})} \mathrm{yr}^{-1}$ input from the stratosphere). All numbers are rounded to the nearest integer.

\begin{tabular}{lcccccc}
\hline Model & Dry & Wet & Total dep. & eminox & $\begin{array}{c}\text { emilnox } \\
\operatorname{Tg}(\mathrm{N}) \mathrm{yr}^{-1}\end{array}$ & Total emi. \\
\hline CESM-CAM-superfast & 17 & 29 & 46 & 42 & 4 & 46 \\
CICERO-OsloCTM2 & 31 & 24 & 54 & & & 52 \\
CMAM & 27 & 23 & 50 & 47 & 4 & 51 \\
GEOSCCM & 12 & 33 & 45 & 40 & 5 & 45 \\
GISS-E2-R & 14 & 39 & 53 & 41 & 8 & 49 \\
GISS-E2-TOMAS & 17 & 37 & 54 & 41 & 8 & 49 \\
MOCAGE & 20 & 27 & 47 & 43 & 5 & 48 \\
NCAR-CAM3.5 & 20 & 29 & 49 & 43 & 4 & 47 \\
STOC-HadAM3 & 26 & 27 & 52 & 44 & 7 & 52 \\
UM-CAM & 31 & 26 & 56 & 49 & 5 & 54 \\
Multi-model mean & 21 & 29 & 51 & 43 & 6 & 49 \\
PhotoComp & & & 51 & & & \\
\hline
\end{tabular}

Table 3. Summary of global totals $\left(\operatorname{Tg}(\mathrm{N}) \mathrm{yr}^{-1}\right.$ ) for year 2000 of deposition and emissions related to the ammonia emissions. "Total" (6th column) is the sum of wet and dry deposition for $\mathrm{NH}_{3}$ and $\mathrm{NH}_{4}$. "eminh3" includes anthropogenic and natural (soils and oceans) emissions. All numbers are rounded to the nearest integer.

\begin{tabular}{lcccccc}
\hline Model & Dry $\mathrm{NH}_{3}$ & ${\text { Wet } \mathrm{NH}_{3}}^{\text {Dry NH}}$ & $\begin{array}{c}\text { Wet } \mathrm{NH}_{4}^{+} \\
\mathrm{Tg}(\mathrm{N}) \mathrm{yr}^{-1}\end{array}$ & Total & eminh3 \\
\hline CICERO-OsloCTM2 & 12 & 9 & 4 & 25 & 50 & 51 \\
GISS-E2-R & 18 & 4 & 3 & 23 & 48 & 47 \\
GISS-E2-TOMAS & 9 & 1 & 5 & 33 & 48 & 48 \\
NCAR-CAM3.5 & 12 & 13 & 6 & 19 & 49 & 49 \\
STOC-HadAM3 & 24 & 6 & 5 & 15 & 50 & 51 \\
Multi-model mean & 15 & 7 & 5 & 23 & 49 & 49 \\
PhotoComp & & & & & 63 & \\
\hline
\end{tabular}

have provided sulfate fields. In all cases, the MMM is constructed using all available model results (Table S5), therefore leading to variations between the various models used in the average.

\section{Description of observational deposition data}

Under the auspices of the World Meteorological Organization (WMO), a precipitation chemistry expert group has performed a critical analysis of available wet deposition data for the years 2000 to 2002 . While dry deposition may be available at specific sites, this is not a directly observed quantity, and we therefore do not use this information. We use the WMO-processed wet deposition dataset in our analysis of the performance of the MMM in the 2000 time slice.

In this dataset, a careful analysis of worldwide reported data of wet precipitation chemistry was made, and data quality qualifiers are provided to deposition data ob- tained mainly from networks in Europe (European Monitoring and Evaluation Programme, EMEP; http://www.nilu. no/projects/ccc/emepdata.html); the United States (National Atmospheric Deposition Program, NADP; http://nadp.sws. uiuc.edu/NTN/ntnData.aspx); Canada (Canadian Air and Precipitation Monitoring Network, CAPMoN; http://www. ec.gc.ca/rs-mn/default.asp?lang=En\&n=752CE271-1); Asia (mainly from the Acid Deposition Monitoring Network in East Asia EANET; http://www.eanet.cc), and Africa (Deposition of Biogeochemically Important Trace Species (DEBITS), http://debits.sedoo.fr). The evaluated wet deposition datasets, soon to be available through the World Data Centre for Precipitation Chemistry, only contain a subset of the available stations for that period, i.e., stations that correspond to regionally representative sites that fulfilled specific quality measures. In this paper, we use the wet deposition measurements of nitrate $\left(\mathrm{NO}_{3}^{-}\right)$, ammonium $\left(\mathrm{NH}_{4}^{+}\right)$and non-seasalt sulfate $\left(\mathrm{SO}_{4}^{2-}\right)$, which were accepted as "satisfactory" 
Table 4. Summary of global totals $\left(\operatorname{Tg}(\mathrm{S}) \mathrm{yr}^{-1}\right)$ for year 2000 of deposition and emissions related to the sulfur emissions. "Total dep." (4th column) is the sum of wet and dry deposition (both sums of $\mathrm{SO}_{2}$ and $\mathrm{SO}_{4}^{2-}$ ), while "Total emi." (8th column) is the sum of $\mathrm{SO}_{2}, \mathrm{SO}_{4}^{2-}$ and DMS emissions. Note that the deposition total should be smaller than the emission total since the formation of sulfate from the oxidation of DMS has a yield smaller than 1; this was estimated to be $87 \%$ in Boucher et al. (2003) when both gas-phase and aqueous-phase reactions are taken into account. All numbers are rounded to the nearest integer.

\begin{tabular}{lccccccc}
\hline Model & Dry & Wet & Total dep. & $\begin{array}{c}\text { emiso2 } \\
\operatorname{Tg}(\mathrm{S}) \mathrm{yr}^{-1}\end{array}$ & emiso4 & emidms & Total emi. \\
\hline CESM-CAM-superfast & 36 & 45 & 81 & 64 & 0 & 19 & 83 \\
CICERO-OsloCTM2 & 32 & 63 & 95 & 65 & 1 & 29 & 96 \\
GISS-E2-R & 51 & 45 & 95 & 65 & 2 & 28 & 95 \\
GISS-E2-TOMAS & 47 & 44 & 91 & 65 & 2 & 28 & 94 \\
NCAR-CAM3.5 & 24 & 55 & 79 & 64 & 0 & 19 & 83 \\
NCAR-CAM5.1 & 25 & 56 & 81 & 65 & 1 & 18 & 84 \\
STOC-HadAM3 & 41 & 43 & 84 & 69 & 0 & 20 & 89 \\
Multi-model mean & 37 & 50 & 87 & 65 & 1 & 23 & 89 \\
PhotoComp & & & 80 & & & & \\
\hline
\end{tabular}

or "conditional" based on a quality assurance review that included expert assessments of measurement methods (wetonly versus bulk sampling, availability of precipitation gauge data, short sample collection periods) and data completeness statistics (annual percent coverage length of precipitation measurements, annual percent of total precipitation measured, and number of years included in the $3 \mathrm{yr}$ average) as specified in the World Meteorological Organization Global Atmosphere Watch Manual for the GAW Precipitation Chemistry Programme (WMO/GAW, 2004). All data are representative of regional, non-urban, non-suburban, non-industrial sites of the aforementioned networks, many of which are located in remote regions of the world. For more detailed information on data networks, data selection criteria, and an application to the HTAP Phase 1 deposition dataset, we refer to Vet et al. (2013), as well as the data networks indicated above. We will focus our present analysis on the NADP, EMEP and EANET observations. This choice was made for consistency with previous analysis (e.g., Dentener et al., 2006) but also for the higher degree of coverage over those regions.

Over Europe (EMEP) and the United States (NADP), deposition measurement sites typically started around the 1980s. We use these early measurements to evaluate the change in deposition over these two decades. To this purpose, we computed from the raw data (available at the aforementioned websites), and using the filtering protocols defined by the specific networks, two sets of 6 yr averages (1980-1985 and 1997-2002 data) for sites that had sufficient observations for both time slices.

Although a quality control similar to the WMO evaluation was not available for the 1980s data, comparison of the WMO processed 2000-2002 data with our 1997-2002 data indicate very good agreement over the respective regions (not shown), validating the suitability of our processed dataset to study changes in deposition from the 1980s to the 2000s.
Historical records of nitrate, ammonium, and sulfur were also developed from high depth resolution measurements in ice cores (see Table S6 for their geographical information) using an established continuous ice core analytical system (e.g., McConnell and Edwards, 2008). Nitrate and ammonium were measured using spectrophotometry and fluorimetry, respectively, with standard flow-through methods (Roethlisberger et al., 2000). Total sulfur concentrations were measured using magnetic sector inductively coupled plasma mass spectrometry (McConnell and Edwards, 2008). At core sites with sufficient annual snowfall, the ice core records were dated using annual layer counting of a range of seasonally varying chemical species (Sigl et al., 2013). Synchronization to well-known volcanic layers was used for dating at core sites with very low snowfall (e.g., East Antarctica) where annual layers are not preserved (Anschütz et al., 2011) or at lower elevation sites (e.g., Akademii Nauk, McCall Glacier, Flade Isblink) where surface melting and percolation make annual layer identification difficult (Opel et al., 2009). Uncertainty ( $1 \sigma)$ in the dating is estimated at $\pm 1 \mathrm{yr}$ for the annually dated sites and \pm 3 yr for all other sites. Decadal averages centered on 1855 and 2000 were computed from the high-resolution measurements.

\section{Evaluation of ACCMIP year 2000 time slice deposition}

While observation and model data are available at the monthly time resolution, we focus our analysis on the annual mean. This choice is made to limit the discussion to the long-term changes in nitrogen and sulfate deposition. In addition to the present intercomparison project, MMM results from two previous studies are available for comparison and analysis of potential improvements: PhotoComp (Dentener et al., 2006) and HTAP (Sanderson et al., 2008; Vet et al., 
Table 5. Summary of statistical analysis of the evaluation of nitrate wet deposition (wetno3), ammonium wet deposition (wetnh4) and sulfate wet deposition (wetso4) for PhotoComp, HTAP and ACCMIP MMM over the 3 main analysis regions. Mean bias (model minus observations), observations and model are in $\mathrm{mg}(\mathrm{N}$ or S $) \mathrm{m}^{-2} \mathrm{yr}^{-1}$.

\begin{tabular}{|c|c|c|c|c|c|c|c|c|c|}
\hline & \multicolumn{9}{|c|}{ wetno3 } \\
\hline & \multicolumn{3}{|c|}{ North America } & \multicolumn{3}{|c|}{ Europe } & \multicolumn{3}{|c|}{ Asia } \\
\hline & PhotoComp & HTAP & ACCMIP & PhotoComp & HTAP & ACCMIP & PhotoComp & HTAP & ACCMIP \\
\hline Linear fit slope & 1.0 & 1.0 & 0.9 & 0.3 & 0.3 & 0.3 & 0.5 & 0.5 & 0.4 \\
\hline Linear fit intercept & 1.0 & 1.0 & 0.9 & 0.3 & 0.3 & 0.3 & 0.5 & 0.5 & 0.4 \\
\hline Mean bias & 34.8 & 21.9 & 44.3 & -41.4 & -60.0 & -75.2 & -47.8 & -49.3 & -46.4 \\
\hline Mean observations & 191.3 & 191.3 & 191.3 & 300.5 & 300.5 & 300.5 & 263.0 & 263.0 & 263.0 \\
\hline Mean model & 226.1 & 213.3 & 235.6 & 259.1 & 240.5 & 225.3 & 215.2 & 213.7 & 216.7 \\
\hline Correlation coefficient & 0.8 & 0.9 & 0.9 & 0.6 & 0.6 & 0.6 & 0.8 & 0.8 & 0.8 \\
\hline \multirow[t]{4}{*}{ Fraction within $\pm 50 \%$} & 77.0 & 84.3 & 68.7 & 75.0 & 85.2 & 85.2 & 84.0 & 84.0 & 88.0 \\
\hline & \multicolumn{9}{|c|}{ wetnh4 } \\
\hline & \multicolumn{3}{|c|}{ North America } & \multicolumn{3}{|c|}{ Europe } & \multicolumn{3}{|c|}{ Asia } \\
\hline & PhotoComp & HTAP & ACCMIP & PhotoComp & HTAP & ACCMIP & PhotoComp & HTAP & ACCMIP \\
\hline Linear fit slope & 0.8 & 0.9 & 0.5 & 0.4 & 0.4 & 0.3 & 0.8 & 0.7 & 0.1 \\
\hline Linear fit intercept & 0.8 & 0.9 & 0.5 & 0.4 & 0.4 & 0.3 & 0.8 & 0.7 & 0.1 \\
\hline Mean bias & 5.5 & 10.9 & -12.1 & -23.9 & -49.7 & -94.7 & -69.7 & -63.4 & -136.2 \\
\hline Mean observations & 161.3 & 161.3 & 161.3 & 336.0 & 336.0 & 336.0 & 400.5 & 400.5 & 400.5 \\
\hline Mean model & 166.8 & 172.2 & 149.2 & 312.1 & 286.4 & 241.3 & 330.8 & 337.1 & 264.4 \\
\hline Correlation coefficient & 0.9 & 0.9 & 0.8 & 0.6 & 0.6 & 0.6 & 0.8 & 0.8 & 0.2 \\
\hline \multirow[t]{4}{*}{ Fraction within $\pm 50 \%$} & 82.2 & 84.8 & 75.7 & 73.9 & 79.5 & 78.4 & 76.0 & 68.0 & 56.0 \\
\hline & \multicolumn{9}{|c|}{ wetso4 } \\
\hline & \multicolumn{3}{|c|}{ North America } & \multicolumn{3}{|c|}{ Europe } & \multicolumn{3}{|c|}{ Asia } \\
\hline & PhotoComp & HTAP & ACCMIP & PhotoComp & HTAP & ACCMIP & PhotoComp & HTAP & ACCMIP \\
\hline Linear fit slope & 0.9 & 1.0 & 0.6 & 0.4 & 0.6 & 0.3 & 0.4 & 0.5 & 0.3 \\
\hline Linear fit intercept & 0.9 & 1.0 & 0.6 & 0.4 & 0.6 & 0.3 & 0.4 & 0.5 & 0.3 \\
\hline Mean bias & 46.3 & 50.0 & -18.8 & -67.2 & 51.5 & -125.3 & -218.6 & -182.1 & -292.4 \\
\hline Mean observations & 309.8 & 309.8 & 309.8 & 404.5 & 404.5 & 404.5 & 686.1 & 686.1 & 686.1 \\
\hline Mean model & 356.1 & 359.8 & 291.0 & 337.3 & 456.1 & 279.3 & 467.5 & 504.1 & 393.7 \\
\hline Correlation coefficient & 0.9 & 0.9 & 0.9 & 0.6 & 0.6 & 0.6 & 0.9 & 0.9 & 0.8 \\
\hline Fraction within $\pm 50 \%$ & 70.4 & 70.0 & 72.2 & 78.7 & 52.8 & 78.7 & 80.0 & 88.0 & 72.0 \\
\hline
\end{tabular}

2013). These previous studies are partially independent of the present one, with different emissions and a different set of models or different versions of the same models. Using the WMO dataset and the model results interpolated to the location of the observing stations, we can statistically analyze the ability of the models to reproduce the observations.

We display in Fig. 1 the global and regional distributions of $\mathrm{NO}_{3}^{-}$(Fig. 1a), $\mathrm{NH}_{4}^{+}$(Fig. 1b) and $\mathrm{SO}_{4}^{2-}$ (Fig. 1c) wet deposition in the MMM compared to the WMO dataset. Deposition is clearly strongly correlated with emissions (i.e., largest in the Northern Hemisphere, but also with larger amounts in areas of biomass burning and large soil emissions such as Central Africa), albeit with significant downwind propagation for each compound. Unlike the nitrogen sources, sulfur emissions from degassing volcanoes (Andres and Kasgnoc, 1998) lead to the formation of deposition hotspots in areas with low anthropogenic emission levels such as Central America.
In the case of $\mathrm{NO}_{3}^{-}$deposition, we find that all 3 experiments (ACCMIP, HTAP and PhotoComp) perform rather similarly (Fig. 2a and Table 5), with correlation coefficients between 0.8 and 0.9 over North America and mean biases ranging from 10 to $20 \%$. However, none of those model simulations are able to capture the observed high deposition rates over East Asia or Europe, possibly due to the proximity of the observing stations to significant sources, features that cannot easily be captured with the coarse grid of presently used models (Zhang et al., 2012). In contrast, in the high emission region of the Northeastern United States, there are regions of overestimation as well as underestimation.

In the case of $\mathrm{NH}_{4}^{+}$, the ACCMIP results are slightly lower than the previous studies over both the North American NADP and European EMEP domains, and therefore have a larger negative bias $(-8 \%$ instead of $3-6 \%)$. Because of errors in the regridding of the $\mathrm{NH}_{3}$ agricultural emissions over China in ACCMIP (see http://www.iiasa.ac.at/web-apps/tnt/RcpDb/dsd? 

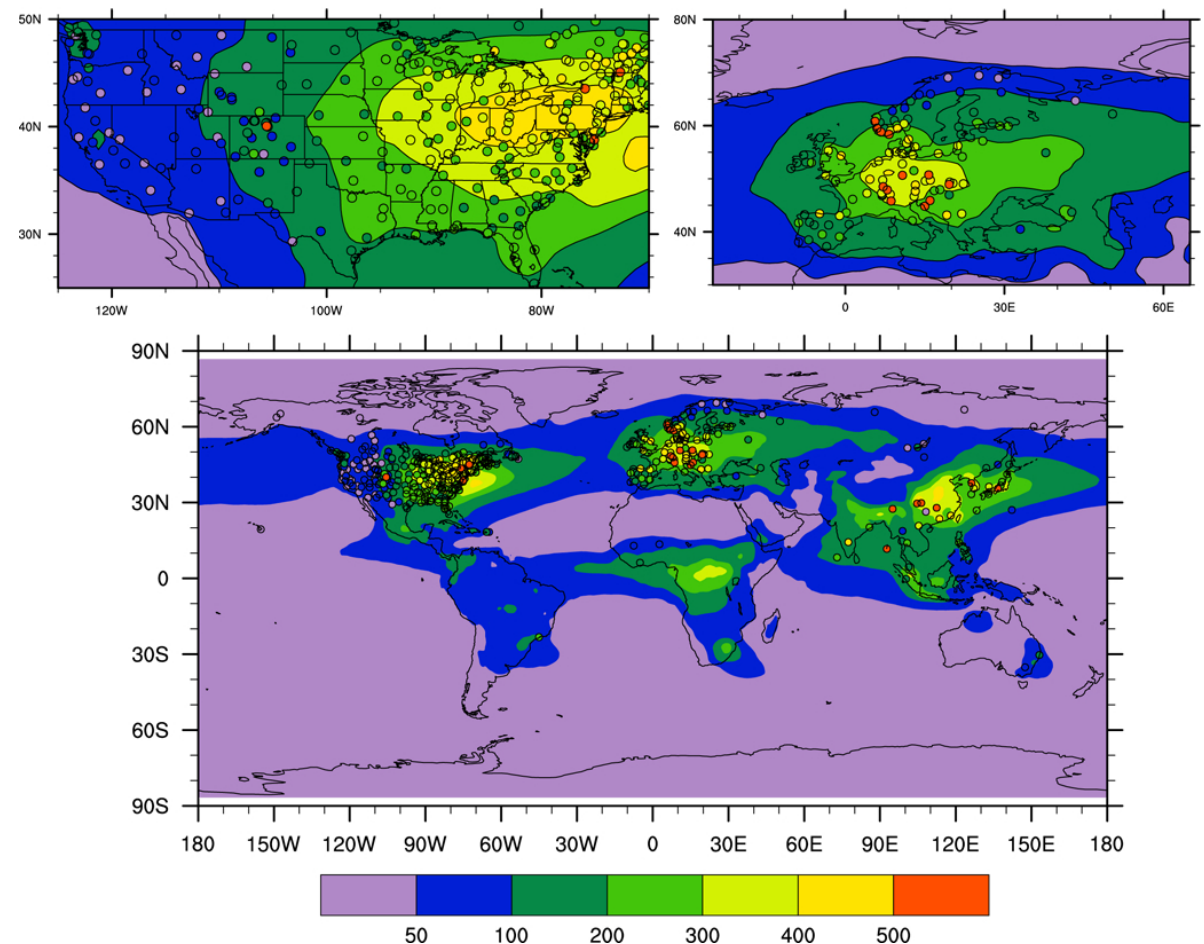

Fig. 1a. Nitrate wet deposition $\left(\mathrm{mg}(\mathrm{N}) \mathrm{m}^{-2} \mathrm{yr}^{-1}\right)$ for 2000. Contours are for the multi-model mean; filled circles are for the wet deposition network observations.

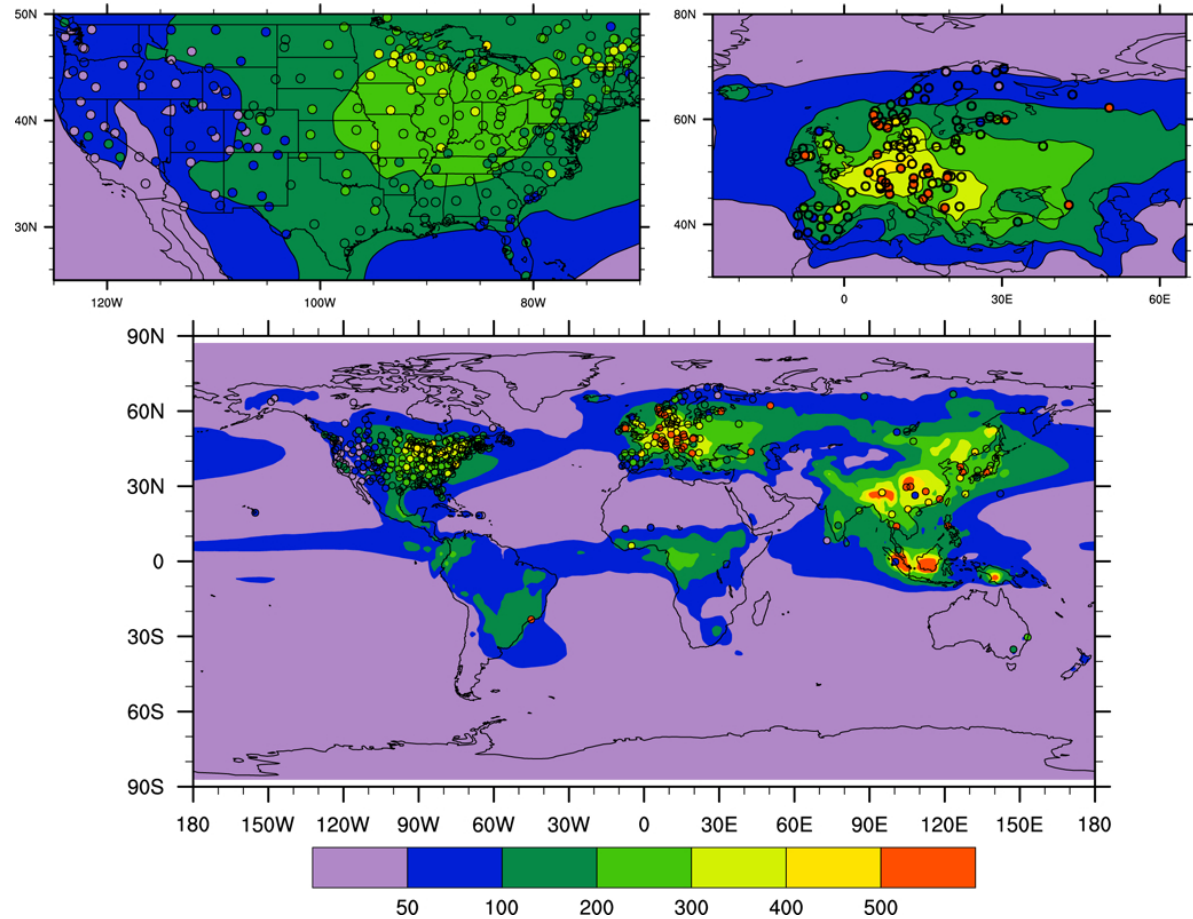

Fig. 1b. Ammonium wet deposition $\left(\mathrm{mg}(\mathrm{N}) \mathrm{m}^{-2} \mathrm{yr}^{-1}\right)$ for 2000. Contours are for the multi-model mean; filled circles are for the wet deposition network observations. 


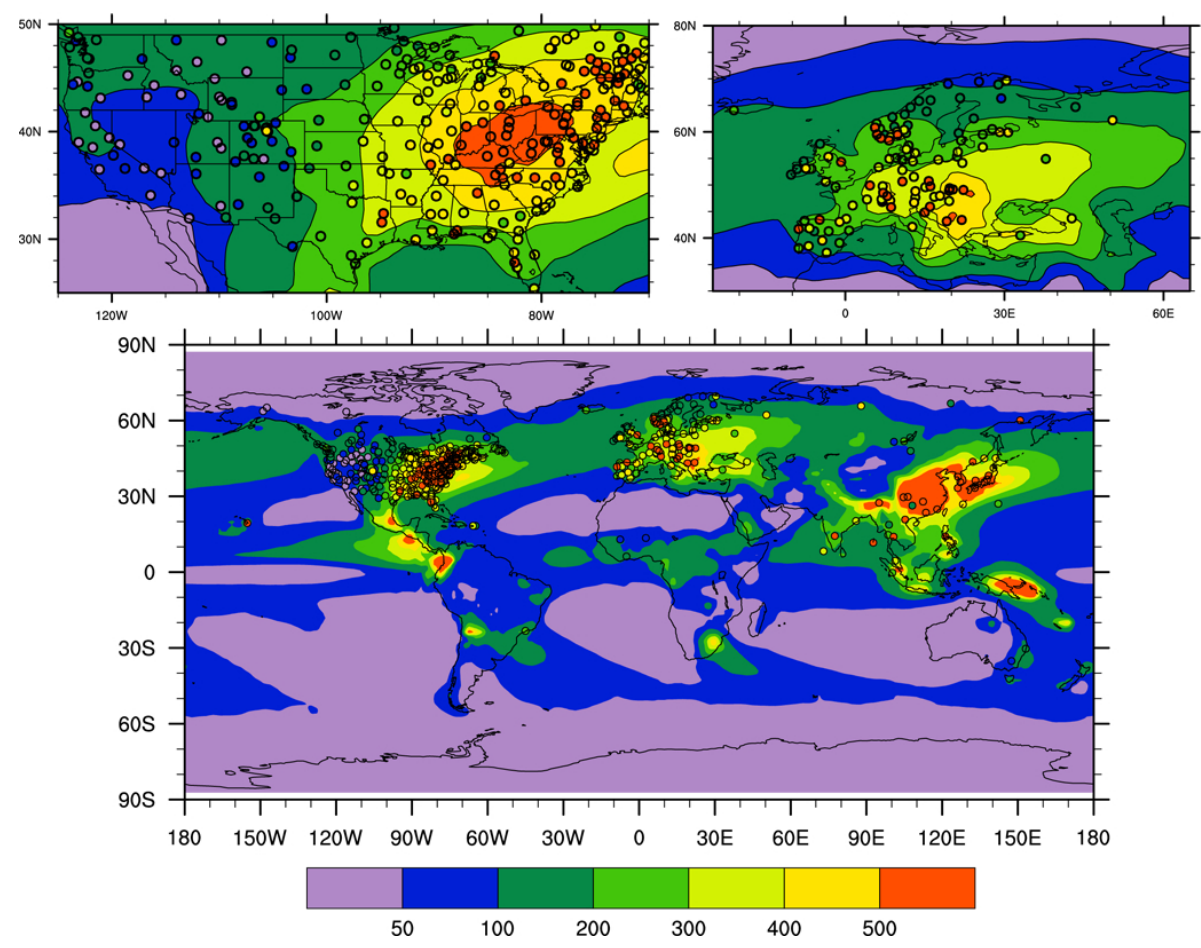

Fig. 1c. Sulfate wet deposition $\left(\mathrm{mg}(\mathrm{S}) \mathrm{m}^{-2} \mathrm{yr}^{-1}\right)$ for 2000. Contours are for the multi-model mean; filled circles are for the wet deposition network observations.

Action $=$ htmlpage $\&$ page $=$ download), the performance in ACCMIP (Fig. 2b and Table 5) is considerably worse than the previous studies over Asia, with a correlation coefficient of 0.2 instead of 0.8 for the PhotoComp and HTAP and a significant underestimate (by approximately 30 to $50 \%$, see Fig. $2 b$ ) for the highest deposition rates over East Asia. Furthermore, because the mapping error involves both China and Mongolia, there is an overestimation of nitrogen deposition from $\mathrm{NH}_{\mathrm{x}}$ in that region. However, no stations are available to provide an estimate of the bias.

The sulfate $\left(\mathrm{SO}_{4}^{2-}\right)$ deposition (Fig. 2c and Table 5) is somewhat improved in ACCMIP over the NADP stations (with a mean bias of $-6 \%$ instead of $15 \%$ ), while the positive bias previously found in the HTAP dataset (12\%) over the EMEP domain is now reversed, so that the ACCMIP models are actually underestimating wet deposition over that region $(-30 \%)$. The deposition over EANET is characterized by a larger negative bias in ACCMIP than PhotoComp or HTAP ( $-42 \%$ instead of -25 to $-32 \%$ ), although the overall correlation remains high $(0.8-0.9)$.

Overall, the performance of the ACCMIP MMM is similar to PhotoComp and HTAP, suggesting that no significant improvement or worsening has been made since those 2 studies in the representation of emissions, chemical processing and deposition processes. The analysis also shows that ammonium deposition over East Asia is most likely underestimated. On the other hand, for all considered species, the
ACCMIP MMM deposition tends to be lower than observed over the EMEP stations.

\section{Evaluation of deposition changes: 1980-2000}

To identify potential changes in deposition over time, we use the 1980 and 2000 time slice experiments. Unfortunately, neither HTAP nor PhotoComp provide historical time slices and therefore such changes cannot be discussed within that context. Over that period, Europe and North America have seen significant changes in nitrogen and sulfur emissions, from a combination of changes in anthropogenic activities and air quality regulations (Granier et al., 2011; Xing et al., 2012).

To limit issues associated with interannual variability (not captured by the ACCMIP model simulations) and uneven time sampling from the observed wet deposition rates, we only select stations with at least 36 months of available data for each $6 \mathrm{yr}$ averaging period (see Sect. 3).

Over the United States, the NADP measured nitrate deposition change between 1980 and 2000 consists mostly of reductions (by $50-100 \mathrm{mg}(\mathrm{N}) \mathrm{m}^{-2} \mathrm{yr}^{-1}$, approximately 10 $20 \%$ ), especially in the eastern portion of the United States (Fig. 3, top row). However, the MMM shows only a minor change over both the eastern and western United States. Indeed, all models except GISS (Table 6) indicate a relative increase in nitrate deposition averaged over the United States. 

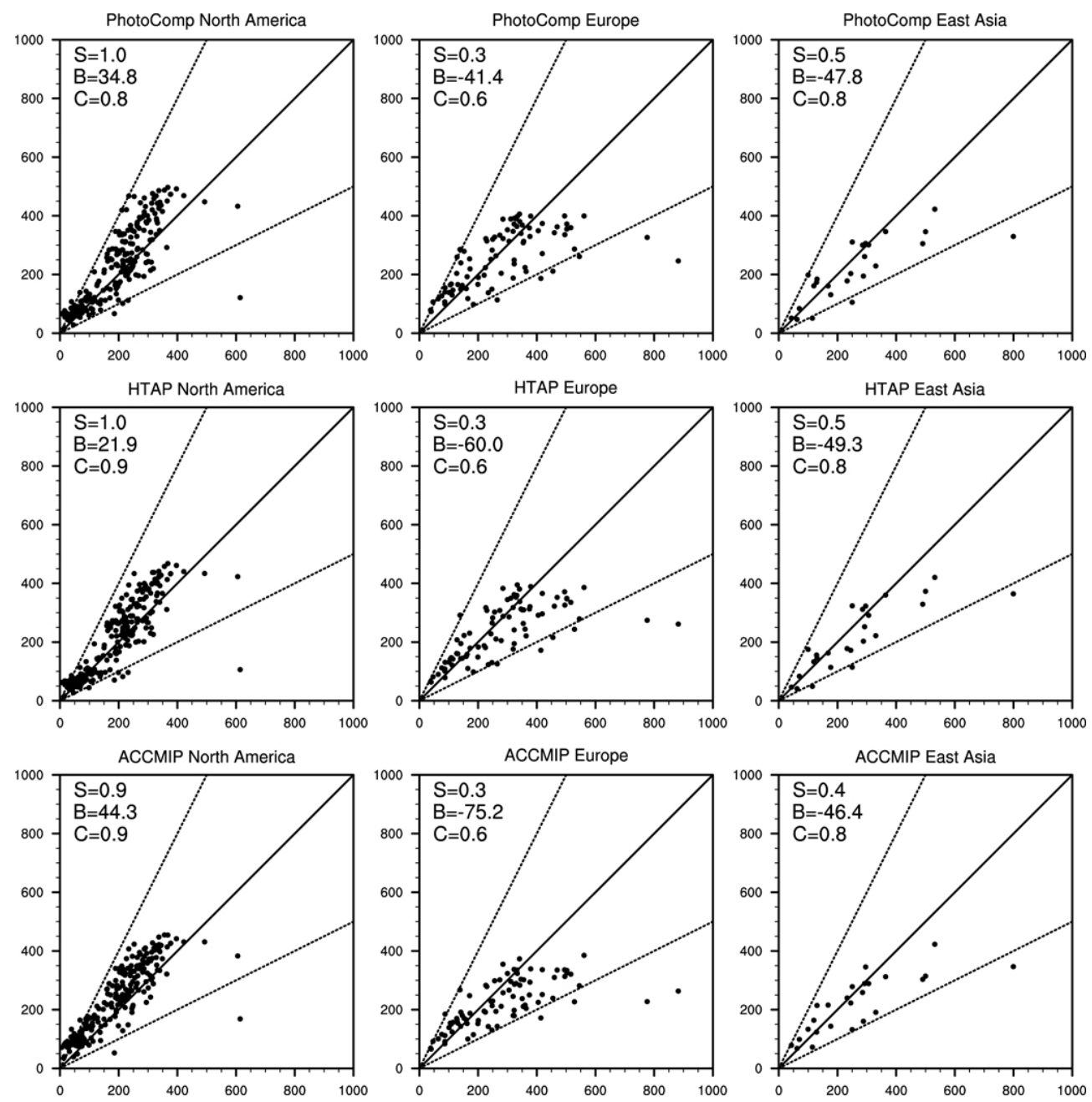

Fig. 2a. Scatter plot ( $x$ axis: observations, $y$ axis: multi-model mean) of nitrate wet deposition $\left(\mathrm{mg}(\mathrm{N}) \mathrm{m}^{-2} \mathrm{yr}^{-1}\right)$ over North America (left column), Europe (middle column) and East Asia (right column). Top row shows the model results from PhotoComp, middle row from HTAP and bottom row from this study. See text for details. $\mathrm{S}=$ slope, $\mathrm{B}=$ mean bias $\left(\mathrm{mg}(\mathrm{N}) \mathrm{m}^{-2} \mathrm{yr}^{-1}\right)$, and $\mathrm{C}=$ correlation (see Table 5).

This simulated increase in wet deposition is a combination of minor increases in $\mathrm{NO}_{\mathrm{x}}$ emissions (Fig. S1a) and in precipitation amounts (Table 6). Based on the CPC Merged Analysis of Precipitation (CMAP; Xie and Arkin, 1997), there is however indication of a small observed decrease in precipitation between 1980 and 2000 over the United States (Fig. S2), while the MMM has limited inter-model agreement and actually shows a slight increase in precipitation when averaged over the whole United States (Table 6). It must however be recognized that the changes over the United States are relatively small and may therefore be strongly affected by interannual variability. Over the EMEP network, many sites indicate a very strong reduction consistent with emission change (Fig. S1a), with the exception of former Yugoslavia and the southern tip of Norway. The MMM captures well the strong reduction, with however a smaller amplitude than is observed at most locations. In this case (Table 6), all models agree on the change in emissions $(-12 \%$ for the mean) and all but
MOCAGE show an increase in precipitation (1.6\% for the mean), the combination of both leading to an overall decrease in deposition ( $-9 \%$ for the mean).

Measured ammonium deposition (Fig. 3, middle row) changes over the NADP network show a mixture of increases and decreases, with again the largest decreases over the Northeastern United States. Similar to nitrate deposition, the MMM is much more uniform than observed and only shows a small decrease in the Midwestern United States. This is due to the fact that the anthropogenic emissions of $\mathrm{NH}_{3}$ are almost identical between 1980 and 2000 (see Fig. S1b). This lack of change in emissions between 1980 and 2000 is possibly erroneous (either in the national total or in its regional distribution), but more analysis is beyond the scope of this paper. Over Europe, the EMEP station data indicate an overall strong decrease, with the exception of sites in France, Italy and Norway. The MMM indicates an overall small decrease over Western Europe and a decrease over Eastern Europe, 

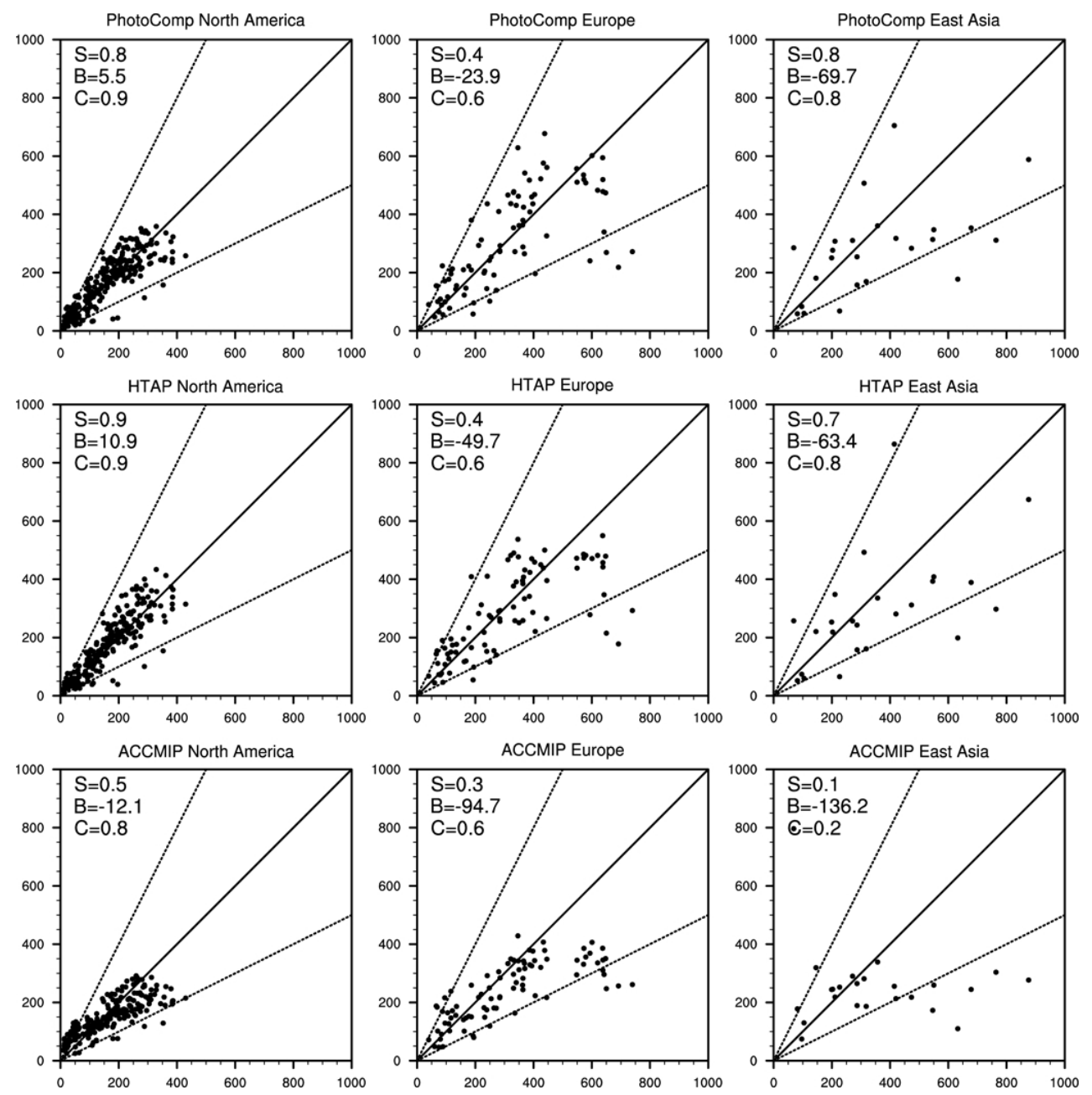

Fig. 2b. Scatter plot ( $x$ axis: observations, $y$ axis: multi-model mean) of ammonium wet deposition $\left(\mathrm{mg}(\mathrm{N}) \mathrm{m}^{-2} \mathrm{yr}^{-1}\right)$ over North America (left column), Europe (middle column) and East Asia (right column). Top row shows the model results from PhotoComp, middle row from HTAP and bottom row from this study. See text for details. $\mathrm{S}=$ slope, $\mathrm{B}=$ mean bias $\left(\mathrm{mg}(\mathrm{N}) \mathrm{m}^{-2} \mathrm{yr}^{-1}\right)$, and C = correlation (see Table 5).

consistent with the significant emission change (Fig. S1b). Local factors, not included in the models, play a role in these differences.

Over the United States, except for a dozen sites scattered over the NADP network, observed sulfate deposition east of $100^{\circ} \mathrm{W}$ (Fig. 3, bottom row) is characterized by large reductions driven by emission change (Fig. S1c). The MMM is, however, underestimating the amplitude of the changes, especially for the largest changes. Over the EMEP network, the MMM captures well the general deposition decrease, including its largest change over Germany (with values larger than $\left.500 \mathrm{mg}(\mathrm{S}) \mathrm{m}^{-2} \mathrm{yr}^{-1}\right)$, clearly driven by the emission change (Fig. S1c).

Overall, the analysis of changes between 1980 and 2000 shows limited agreement between MMM and observations over the United States. In particular, the observed changes over the NADP network indicate much higher variability and amplitude than is simulated, driven by fairly small changes in emissions. Also, this analysis highlights the potential misrepresentation of the $\mathrm{NH}_{3}$ emission change over the United States between 1980 and 2000. While the deposition change over Europe from the MMM is not as large as observed, the overall patterns of change are better represented, except for $\mathrm{NH}_{\mathrm{x}}$ deposition over Western Europe. This suggests that $\mathrm{NO}_{\mathrm{x}}$ (and to a lesser extent $\mathrm{SO}_{\mathrm{x}}$ and $\mathrm{NH}_{\mathrm{x}}$ ) emissions changes may be better captured over Europe in the historical emission dataset used in ACCMIP (Lamarque et al., 2010), since emission change is the main driver for deposition change. However, further analysis is required for a complete understanding of the applicability of deposition data to constrain emission inventories.

\section{Evaluation of deposition changes: 1850-2000}

In addition to recent surface measurements, we use ice core records of deposition over the Northern Hemisphere and 

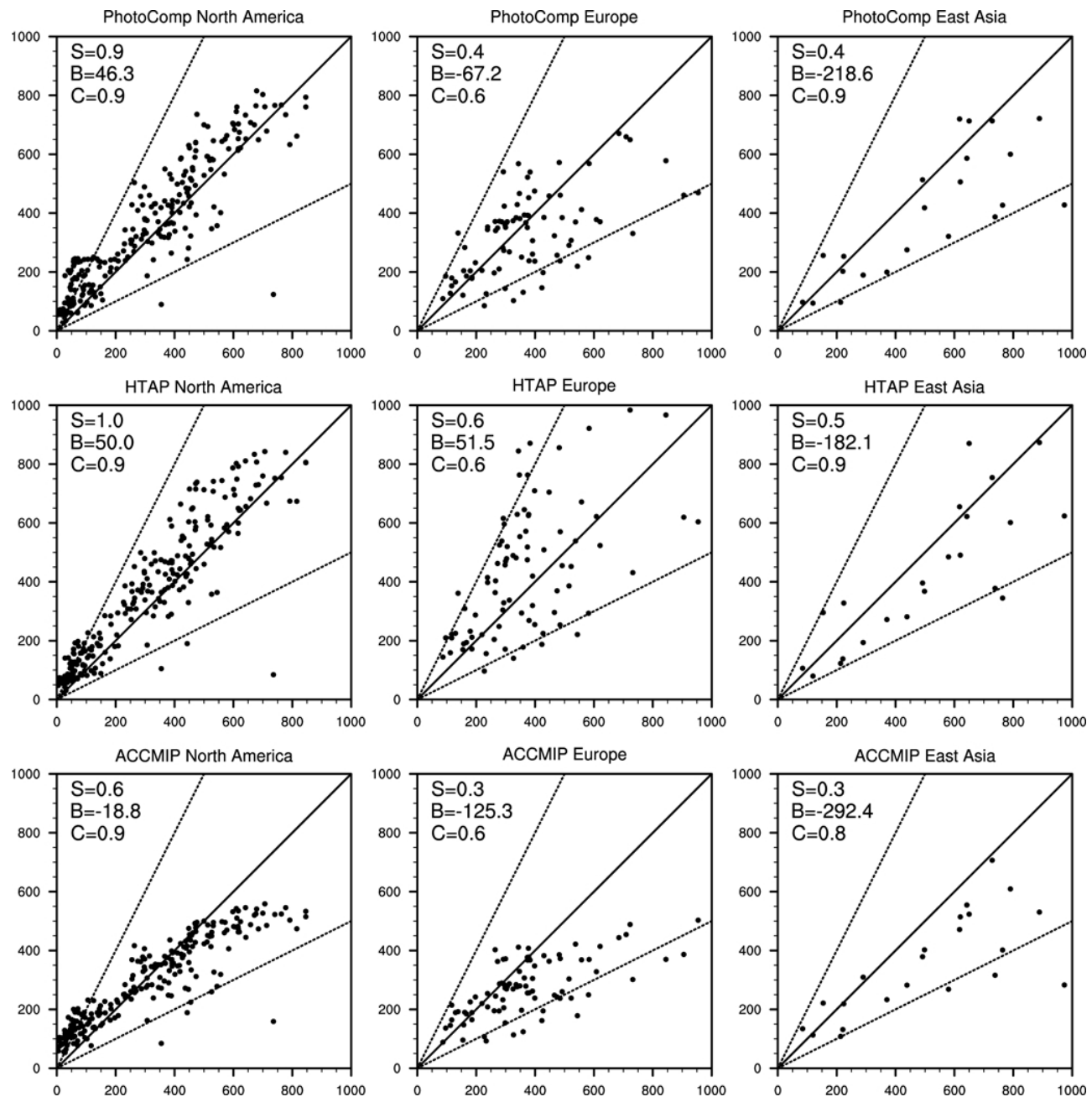

Fig. 2c. Scatter plot ( $x$ axis: observations, $y$ axis: multi-model mean) of sulfate wet deposition $\left(\mathrm{mg}(\mathrm{S}) \mathrm{m}^{-2} \mathrm{yr}^{-1}\right.$ ) over North America (left column), Europe (middle column) and East Asia (right column). Top row shows the model results from PhotoComp, middle row from HTAP and bottom row from this study. See text for details. $\mathrm{S}=$ slope, $\mathrm{B}=$ mean bias $\left(\mathrm{mg}(\mathrm{S}) \mathrm{m}^{-2} \mathrm{yr}^{-1}\right)$, and $\mathrm{C}=$ correlation (see Table 5).

Table 6. Relative change 2000 minus 1980 (expressed in \%, relative to 1980) for $\mathrm{NO}_{\mathrm{y}}$ wet deposition (wetnoy), $\mathrm{NO}_{\mathrm{x}}$ emissions (eminox) and total precipitation (precip) averaged over the region of interest. CICERO-OsloCTM2 uses the same climate for all simulations and therefore does not simulate any precipitation change.

\begin{tabular}{|c|c|c|c|c|c|c|}
\hline \multirow[b]{2}{*}{ Model } & \multicolumn{3}{|c|}{ United States } & \multicolumn{3}{|c|}{ Europe } \\
\hline & wetnoy & eminox & precip & wetnoy & eminox & precip \\
\hline CESM-CAM-superfast & 4.8 & 0.6 & 4.2 & -1.4 & -14.2 & 0.5 \\
\hline CICERO-OsloCTM2 & 6.2 & 0.3 & 0 & -7.3 & -13.6 & 0 \\
\hline CMAM & 7.3 & 3.8 & -1.7 & -12.7 & -9.2 & 1.9 \\
\hline GEOSCCM & 2.4 & 1.2 & -0.6 & -15.5 & -13.6 & 0.3 \\
\hline GISS-E2-R & -0.8 & -2.4 & -0.3 & -14.2 & -11.3 & 2.9 \\
\hline GISS-E2-TOMAS & 6.2 & 1.6 & -0.3 & -9.6 & -10.8 & 2.9 \\
\hline MOCAGE & 4.8 & 1.6 & 1.8 & -3.1 & -11.1 & -3.3 \\
\hline NCAR-CAM3.5 & 6.5 & 1.6 & 2.4 & -12.1 & -13.2 & 0.8 \\
\hline STOC-HadAM3 & 9.9 & 1.8 & 2.6 & -4.7 & -10.6 & 4.1 \\
\hline UM-CAM & 2.7 & -2.0 & -0.2 & -4.9 & -13.2 & 4.1 \\
\hline Multi-model mean & 4.9 & 0.8 & 0.9 & -8.9 & -12.1 & 1.6 \\
\hline
\end{tabular}



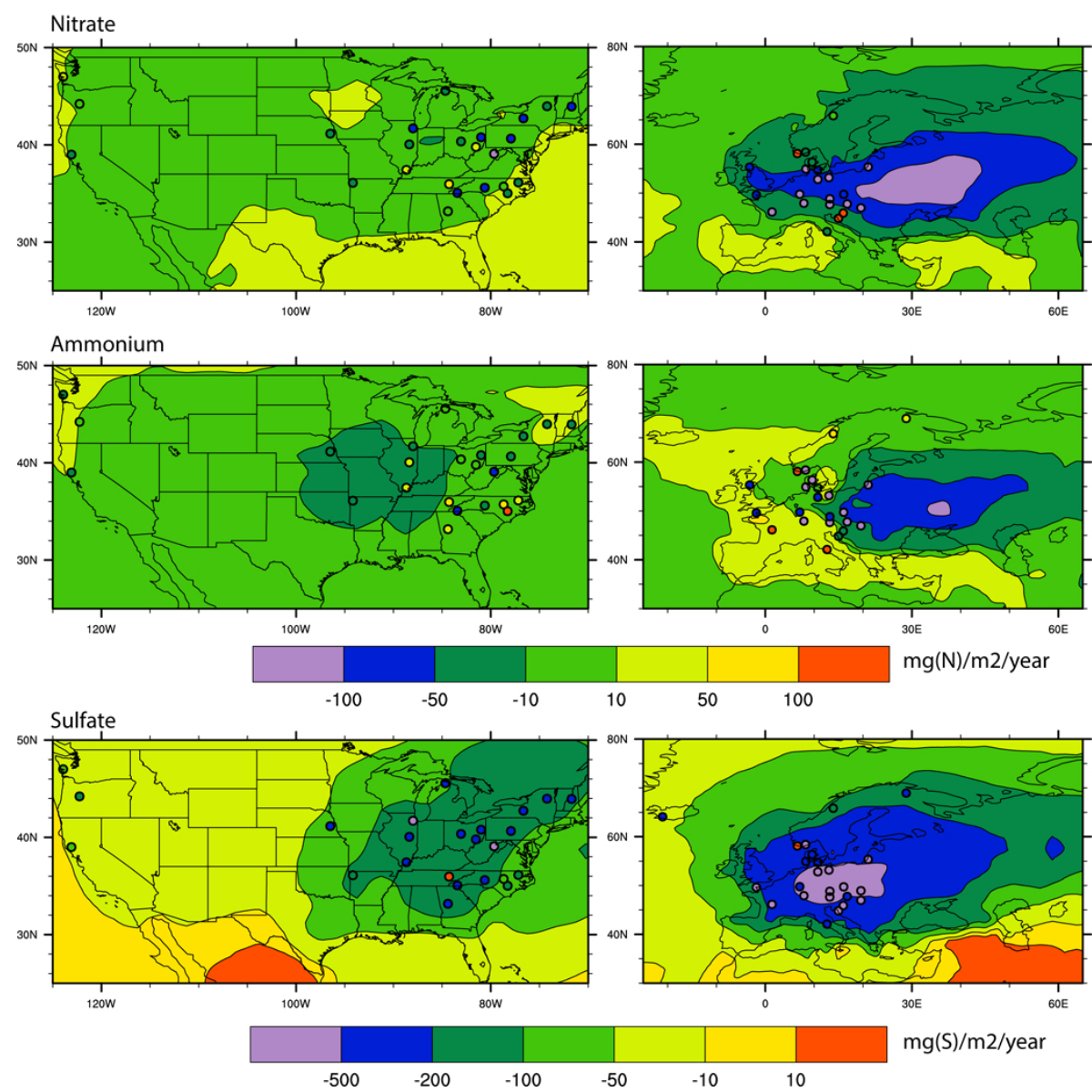

Fig. 3. Change in deposition (2000-1980) over the NADP (left column) and EMEP (right column) networks. Top row is for nitrate $\left(\mathrm{mg}(\mathrm{N}) \mathrm{m}^{-2} \mathrm{yr}^{-1}\right)$, middle row is for ammonium $\left(\mathrm{mg}(\mathrm{N}) \mathrm{m}^{-2} \mathrm{yr}^{-1}\right)$, and bottom row is for sulfate $\left(\mathrm{mg}(\mathrm{S}) \mathrm{m}^{-2} \mathrm{yr}^{-1}\right) . \mathrm{Contours} \operatorname{are~the}$ MMM results, filled circles are the observations.

Antarctica to study the ability of models to represent changes since 1850 . To limit the importance of interannual variability in the ice core record, we use the average values for 1850 1860 and 1995-2005 to compare against the 1850 and 2000 time slices, respectively. As a basic test of the applicability of the MMM to the polar regions, we show in Fig. S3 a comparison of year 2000 precipitation against the gauge-based climatology of Yang et al. (2005). We find that the MMM provides a regional distribution of precipitation consistent with the observations (including the annual amount) throughout the Arctic circle poleward of $60^{\circ} \mathrm{N}$, with the caveat that no rain gauges are available over central Greenland. Additional analysis of precipitation over the Arctic is provided in Lee et al. (2013). No equivalent data are available for Antarctica.

We find that there is a strong agreement between the 1850 observed and simulated nitrate depositions (Fig. 4a), both in regional structure and intensity. Nitrate deposition in 2000 is however overestimated at all Northern Hemisphere sites but one. In contrast, the year 2000 simulated deposition over Antarctica, which is much less affected by changes in anthro- pogenic $\mathrm{NO}_{\mathrm{x}}$ emissions but still shows an overall increase in nitrate deposition, is in good agreement with the observations.

Ammonium deposition (Fig. 4b) is strongly overestimated at the Greenland sites in both 1850 and 2000 time slices (and so is the change 2000 minus 1850; not shown). Wolff et al. (2013) argue that it is actually difficult to derive a change of measured $\mathrm{NH}_{4}^{+}$deposition over Greenland, due to the large dependency on the highly variable contribution of biomass burning to $\mathrm{NH}_{4}^{+}$deposition. However, the other two sites in the Northern Hemisphere (McCall, Alaska, and Akademii Nauk, Siberia; see Table S6 for their exact locations) are well captured. This is true for the 2000 time slice as well, where the McCall glacier shows a decrease since 1850 , possibly associated with a change in biomass burning emissions over North America. Over Antarctica, ammonium deposition rates over the eastern portion of the ice sheet are well represented, while they are somewhat overestimated in the western sector. This is the case for both 1850 and 2000. Increases in the simulated deposition between 1850 and 2000 

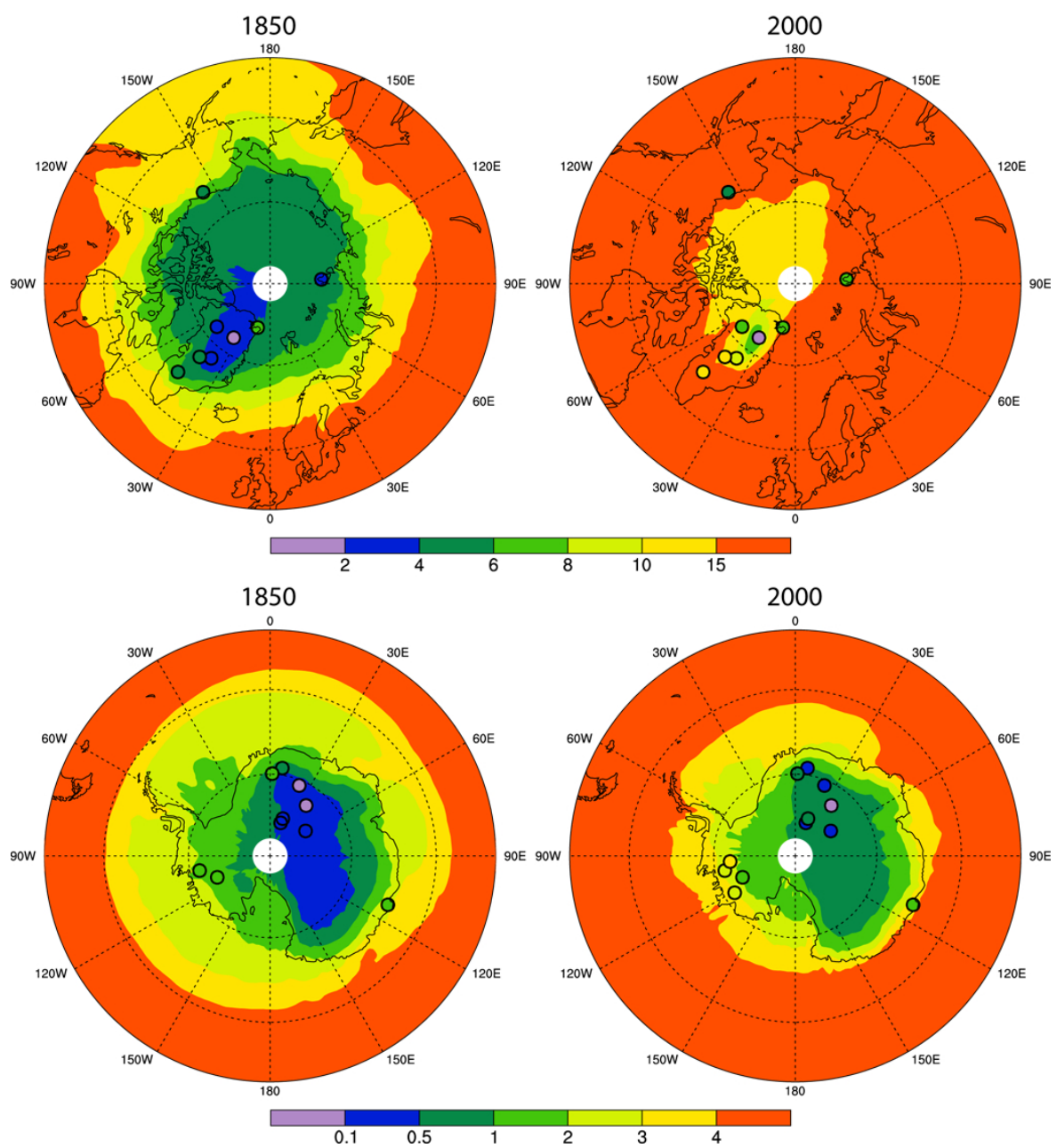

Fig. 4a. Nitrate deposition from ice cores $\left(\mathrm{mg}(\mathrm{N}) \mathrm{m}^{-2} \mathrm{yr}^{-1}\right.$, filled circles, see Table S5) and MMM for 1850 (left column) and 2000 (right column). Top panel is for the Arctic region; bottom panel is for the Antarctic region. Contours are the MMM results; filled circles are the observations. Note different color scales between top and bottom panels.

seem to be larger than observed, albeit the levels of deposition are small compared to those observed in the Northern Hemisphere.

Sulfate deposition in 1850 (Fig. 4c) is represented quite well at the Northern Hemisphere except for McCall, Alaska, and central Greenland (Tunu glacier). Over Antarctica, the deposition tends to be slightly lower than observed, but with an accurate representation of the east-west gradient. Sulfate deposition in 2000 is overestimated at all ice core sites of the Northern Hemisphere. Sulfate deposition over Antarctica has a well-defined east-west separation, well captured by the model. There is little variation between 1850 and 2000 since the sulfate production there is primarily driven by DMS oxidation. In many models used in ACCMIP, the DMS source does not vary with time, although CameronSmith et al. (2011) suggest it should, and changes in DMS emissions could represent an important feedback in the climate system (Charlson et al., 1987).
Overall, the ice core comparison of the MMM indicates a reasonable representation of the preindustrial (1850) conditions but tends to overestimate the present-day (2000) conditions. Similar conclusions are found for 1980 (not shown), indicating that biases in the year 2000 deposition fields are not related to recent transient features.

\section{Total nitrogen and sulfate deposition 1850-2100}

In this section, we document the MMM global and regional distributions of total deposition (wet + dry) of $\mathrm{NO}_{\mathrm{y}}, \mathrm{NH}_{\mathrm{x}}$ and $\mathrm{SO}_{\mathrm{x}}$, and their changes from 1850 to 2100 under the RCP2.6, 4.5 and 8.5 projection scenarios (Fig. 5, Fig. S5 and Tables S2-S4; note that these tables also include regional emission totals).

The historical increase of $\mathrm{NO}_{\mathrm{y}}$ deposition (Fig. 5a) since 1850 took place mostly in the Northern Hemisphere. It is characterized by deposition rates larger than 

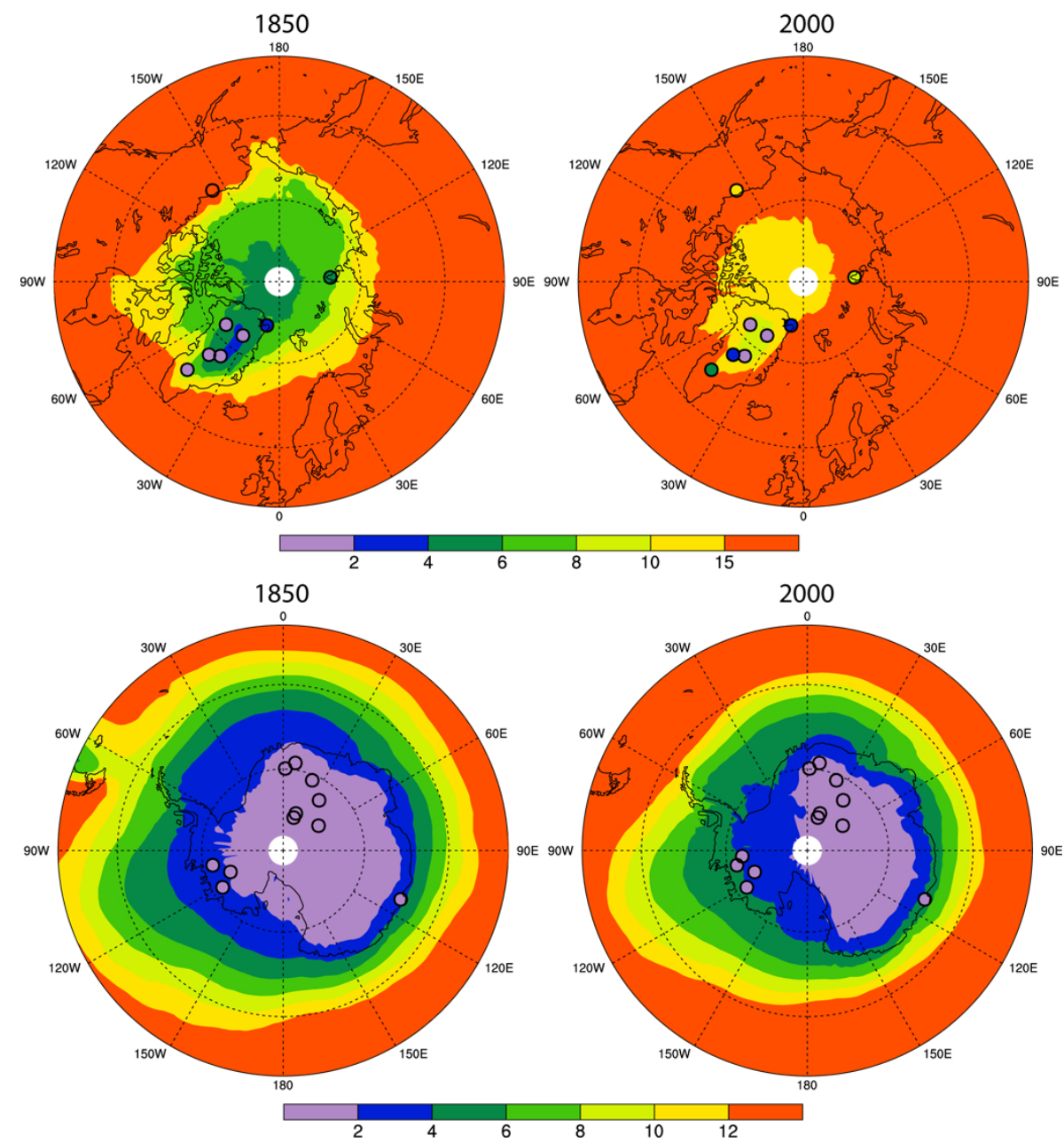

Fig. 4b. Ammonium deposition from ice cores $\left(\mathrm{mg}(\mathrm{N}) \mathrm{m}^{-2} \mathrm{yr}^{-1}\right.$, filled circles, see Table S5) and MMM for 1850 (left column) and 2000 (right column). Top panel is for the Arctic region; bottom panel is for the Antarctic region. Contours are the MMM results; filled circles are the observations. Note different color scales between top and bottom panels.

$100 \mathrm{mg}(\mathrm{N}) \mathrm{m}^{-2} \mathrm{yr}^{-1}$ over most of the continental areas, the North Atlantic and the outflow oceanic areas of Eastern Asia, the Indian subcontinent and Central Africa. By 2030, the projections over the United States and Europe are quite similar for RCP2.6 and RCP4.5, while RCP8.5 shows a smaller reduction from the 2000 levels. In Eastern Asia, deposition of $\mathrm{NO}_{\mathrm{y}}$ is showing levels above 2000 , with the largest increase seen in RCP8.5. However, over the Indian subcontinent the largest deposition increases were found in RCP4.5. Only small changes occur in the Southern Hemisphere. By 2100 , most of the continental areas, except for India, are projected to return to pre-1980 levels of deposition. Another exception is the larger deposition over the northern Pacific Ocean in RCP8.5, consistent with increased $\mathrm{NO}_{\mathrm{x}}$ emissions from shipping. Since the $\mathrm{MMM} \mathrm{NO}_{\mathrm{y}}$ deposition is computed from the largest number of models, it is reasonable to document inter-model variability for that diagnostic (Fig. S6). We find that over most continental areas and for most time slices, the inter-model standard deviation is in the 10-20\% range, with Central Asia and South America being somewhat larger (20-30\%). The higher standard deviation over South America stems from variations in soil emissions, while the variability over Central Asia is mostly related to precipitation differences (not shown).

While the increases in nitrogen deposition from ammonia emissions between 1850 and 2000 affect the various regions similarly to the impact of $\mathrm{NO}_{\mathrm{x}}$ emissions (Fig. 5b), the RCP projections for $\mathrm{NH}_{3}$ emissions are indicative of a very different trajectory (Lamarque et al., 2011) with continuous increases over most regions, with the exception of the oceans south of $30^{\circ} \mathrm{S}$. These deposition changes are mainly driven by the projected increases in inorganic fertilizer use needed to provide more and higher quality food for a growing worldwide population, with no policies in places to abate the emissions. 

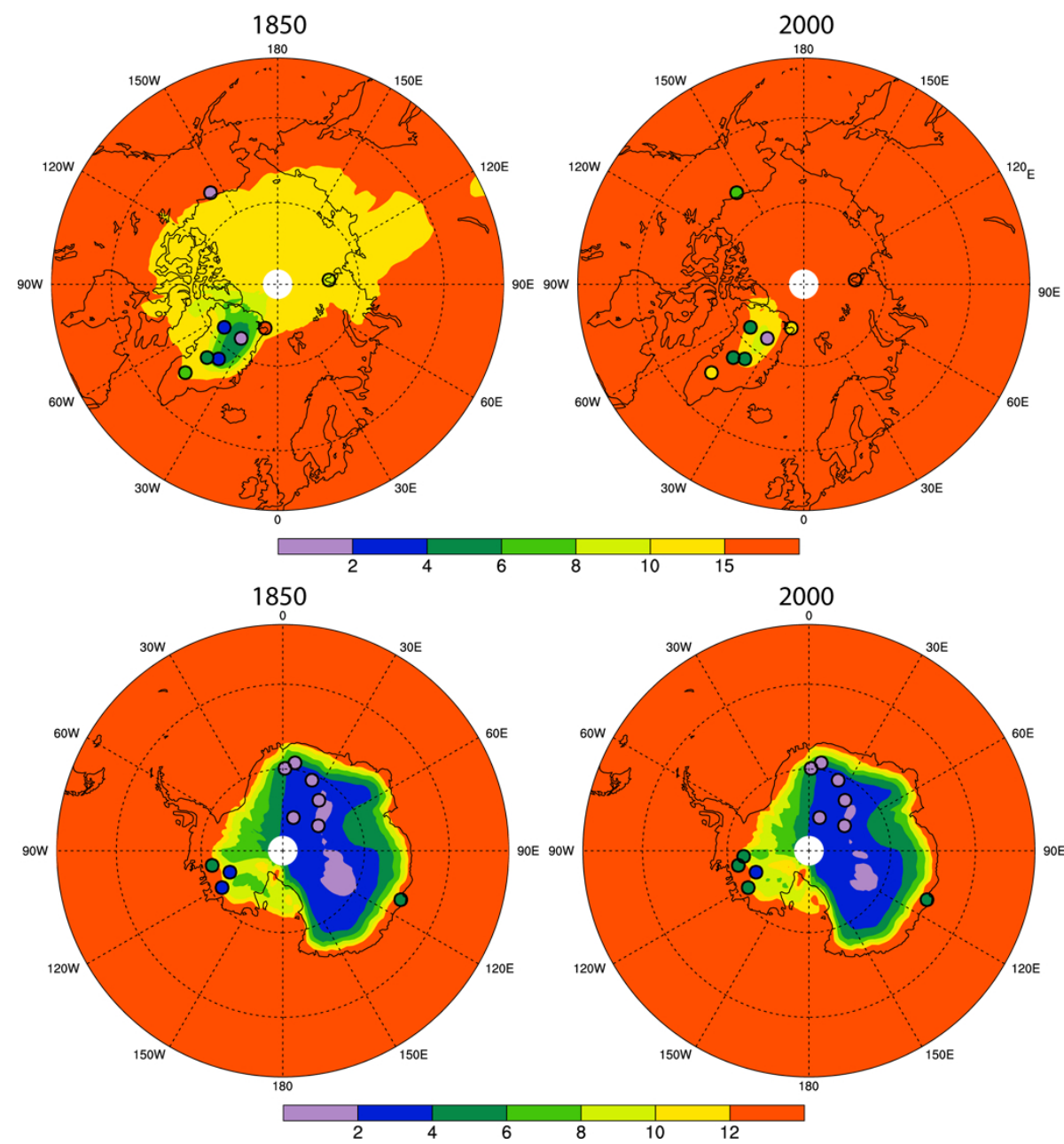

Fig. 4c. Sulfate deposition from ice cores $\left(\mathrm{mg}(\mathrm{S}) \mathrm{m}^{-2} \mathrm{yr}^{-1}\right.$, filled circles, see Table S5) and MMM for 1850 (left column) and 2000 (right column). Top panel is for the Arctic region; bottom panel is for the Antarctic region. Contours are the MMM results; filled circles are the observations. Note different color scales between top and bottom panels.

Simulated sulfate deposition grew and was more widespread in Europe than North America in 1980, but was similar in both regions by 2000 . The only significant increase between 1980 and 2000 is over China, associated with its increasing use of coal for power generation (Smith et al., 2011). The projected changes over these regions indicate a gradual phaseout of anthropogenic $\mathrm{SO}_{2}$ emissions by 2100 , including over China. Even by 2030, emissions over China are projected to be no larger than in 2000 , a trend that might be reflected in the most recent estimates over China (Smith et al., 2011; Klimont et al., 2013). Similar to $\mathrm{NO}_{\mathrm{y}}$ deposition, only the Indian subcontinent is projected in RCP8.5 to have sulfate deposition levels higher in 2100 than in 1980. Sulfate deposition over the oceans is also considerably reduced in the RCP scenarios, but depends on the specific scenario's projection of shipping emissions.

The combination of deposition fluxes as $2 \cdot \mathrm{SO}_{\mathrm{x}}+\mathrm{NO}_{\mathrm{y}}-$ $\mathrm{NH}_{\mathrm{x}}$ provides an indication of the degree of additional acid- ity (Keene et al., 1983) contained in the deposited fluxes from the emissions of the precursor compounds (Fig. 6). In particular, it shows that over the 21 st century continental areas over the Northern Hemisphere will have a tendency towards more basic deposition with the increase of $\mathrm{NH}_{3}$ emissions. This analysis also clearly shows the spurious $\mathrm{NH}_{3}$ emissions over Mongolia (as discussed in Sect. 4).

Following the discussion of averaged deposition rates over various regions in Lamarque et al. (2011, see their Tables 5 and 6; note that the NCAR-CAM3.5 results used in the present ACCMIP analysis are equivalent to results in this previous analysis), we present the same diagnostics here (in the same units), with the exception of RCP6.0 (Tables 7 and 8). Overall, the total (from $\mathrm{NO}_{\mathrm{y}}$ and $\mathrm{NH}_{\mathrm{x}}$ combined, since both affect vegetation in the same fashion) nitrogen deposition is expected to increase between 2000 and 2100 over many regions, especially in the case of RCP8.5. Only Western Europe and North America are projected to see a reduction in 


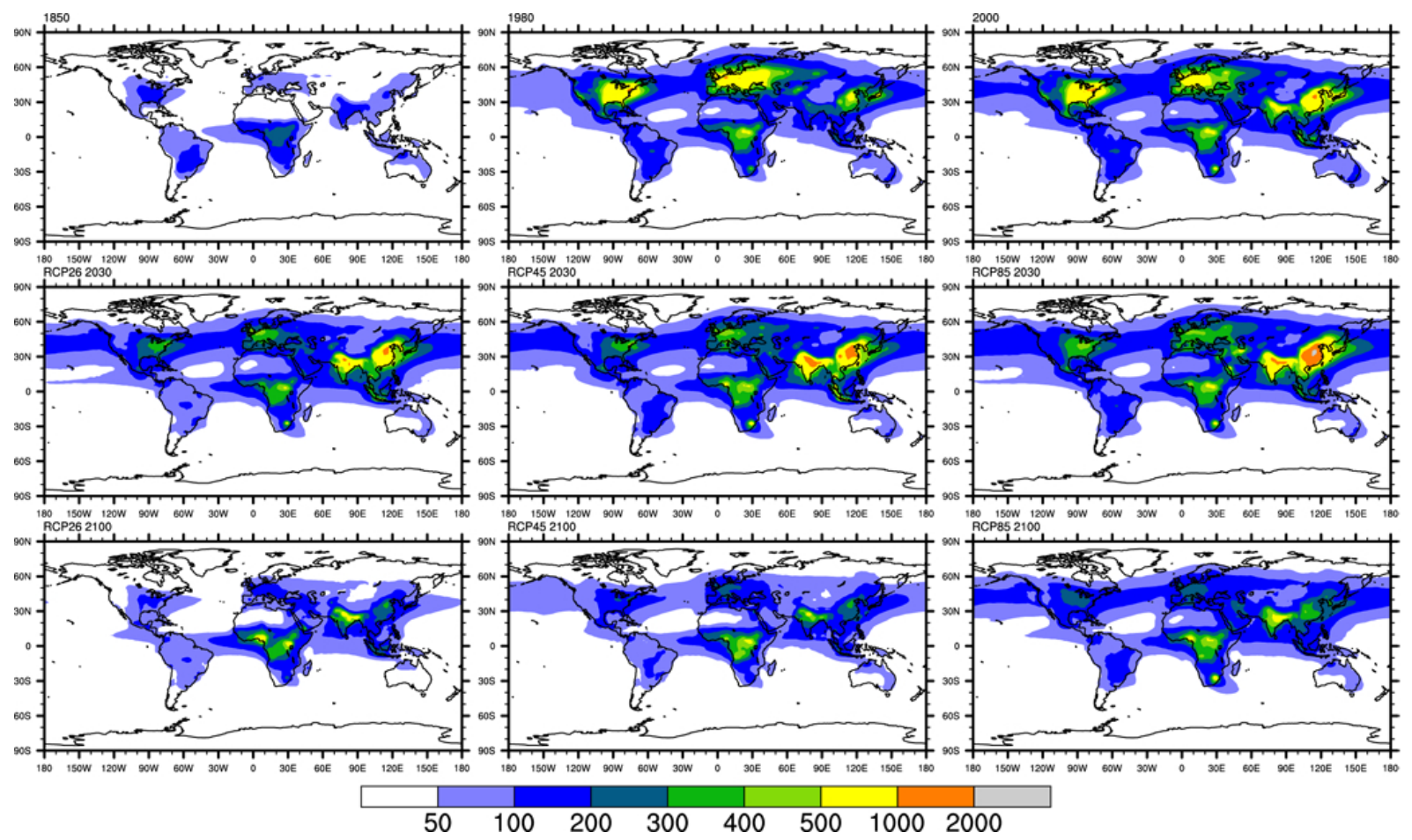

Fig. 5a. Total (wet + dry) $\mathrm{NO}_{\mathrm{y}}$ deposition $1850-2100\left(\mathrm{mg}(\mathrm{N}) \mathrm{m}^{-2} \mathrm{yr}^{-1}\right)$. Top row shows 1850,1980 and 2000 . Middle row shows 2030 for RCP2.6, RCP4.5 and RCP8.5. Bottom row shows 2100 for RCP2.6, RCP4.5 and RCP8.5.

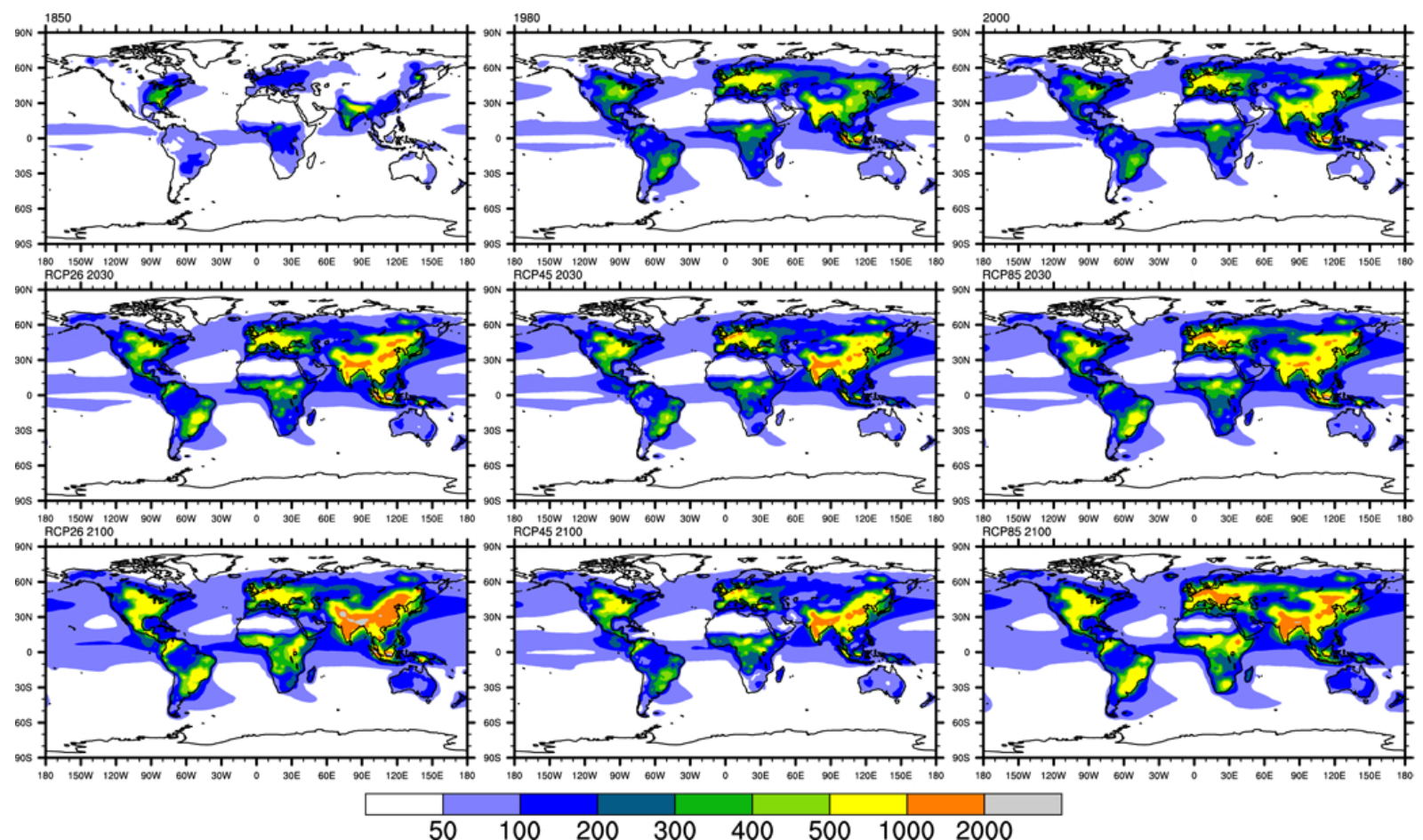

Fig. 5b. Total (wet + dry) $\mathrm{NH}_{\mathrm{x}}$ deposition $1850-2100\left(\mathrm{mg}(\mathrm{N}) \mathrm{m}^{-2} \mathrm{yr}^{-1}\right)$. Top row shows 1850,1980 and 2000 . Middle row shows 2030 for RCP2.6, RCP4.5 and RCP8.5. Bottom row shows 2100 for RCP2.6, RCP4.5 and RCP8.5. 


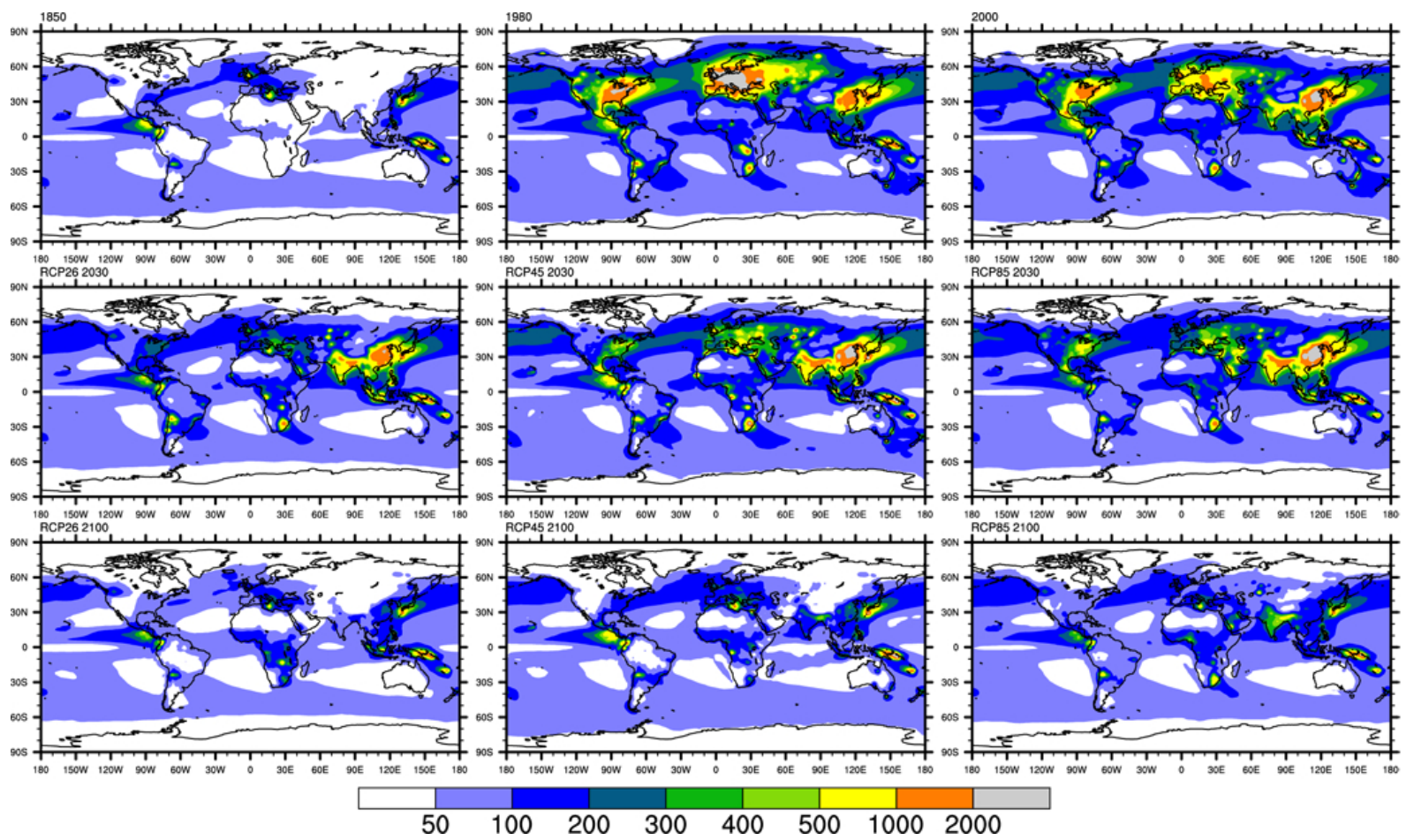

Fig. 5c. Total (wet + dry) $\mathrm{SO}_{\mathrm{x}}$ deposition $1850-2100\left(\mathrm{mg}(\mathrm{S}) \mathrm{m}^{-2} \mathrm{yr}^{-1}\right)$. Top row shows 1850,1980 and 2000 . Middle row shows 2030 for RCP2.6, RCP4.5 and RCP8.5. Bottom row shows 2100 for RCP2.6, RCP4.5 and RCP8.5.
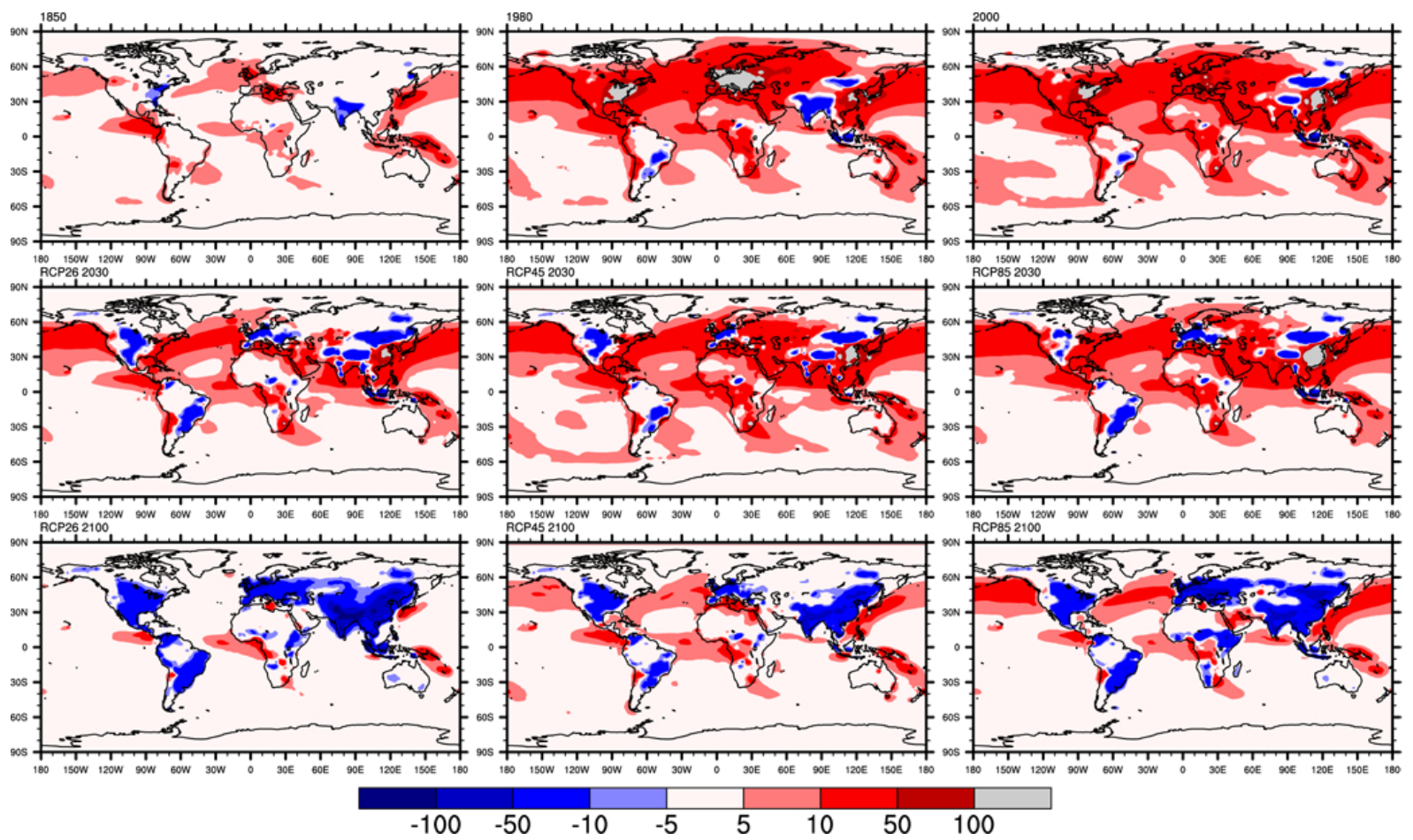

Fig. 6. Time evolution of added deposition acidity $\left(10^{-6} \mathrm{~mol} \mathrm{~m} \mathrm{yr}^{-1}\right)$ computed as $2 \cdot \mathrm{SO}_{\mathrm{X}}+\mathrm{NO}_{\mathrm{y}}-\mathrm{NH}_{\mathrm{X}}$. Blue regions indicate areas where deposition is more basic than it would have been without those respective emissions. Top row shows 1850,1980 and 2000 . Middle row shows 2030 for RCP2.6, RCP4.5 and RCP8.5. Bottom row shows 2100 for RCP2.6, RCP4.5 and RCP8.5. 
Table 7. Average $\mathrm{MMM}$ nitrogen $\left(\mathrm{NH}_{\mathrm{x}}+\mathrm{NO}_{\mathrm{y}}\right)$ deposition $\left(\mathrm{mg}(\mathrm{N}) \mathrm{m}^{-2} \mathrm{yr}^{-1}\right)$ over specific regions as defined in Lamarque et al. (2011).

\begin{tabular}{lcccc}
\hline Region & 2000 & $\begin{array}{c}\text { RCP2.6 } \\
2100\end{array}$ & $\begin{array}{c}\text { RCP4.5 } \\
2100\end{array}$ & $\begin{array}{c}\text { RCP8.5 } \\
2100\end{array}$ \\
\hline Canada & 203 & 150 & 148 & 201 \\
USA & 613 & 416 & 412 & 550 \\
Mexico & 412 & $464^{*}$ & 351 & $503^{*}$ \\
C. America & 264 & $313^{*}$ & 242 & $287^{*}$ \\
Brazil & 341 & $397^{*}$ & 299 & $465^{*}$ \\
Rest of S. America & 253 & $369^{*}$ & 253 & $359^{*}$ \\
N. Africa & 174 & 139 & 132 & $211^{*}$ \\
W. Africa & 396 & $524^{*}$ & $450^{*}$ & $573^{*}$ \\
E. Africa & 287 & $461^{*}$ & $355^{*}$ & $570^{*}$ \\
S. Africa & 297 & $389^{*}$ & 258 & $458^{*}$ \\
W. Europe & 768 & 448 & 467 & 662 \\
C. Europe & 1061 & 685 & 577 & $1256^{*}$ \\
Turkey & 693 & 541 & 512 & 657 \\
Ukraine & 859 & 584 & 415 & $1049^{*}$ \\
Kazakhstan area & 297 & $361^{*}$ & 201 & $328^{*}$ \\
Russia & 289 & 205 & 188 & $304^{*}$ \\
Middle East & 263 & $278^{*}$ & 190 & $383^{*}$ \\
South Asia & 728 & $1550^{*}$ & $1023^{*}$ & $1318^{*}$ \\
Korea region & 1058 & 921 & 751 & 894 \\
East Asia & 756 & $1021^{*}$ & 690 & $888^{*}$ \\
Southeast Asia & 661 & $827^{*}$ & 569 & $752^{*}$ \\
Indonesia & 658 & $694^{*}$ & 297 & 417 \\
Japan & 789 & 447 & 447 & 660 \\
Oceania & 126 & $133^{*}$ & 118 & $153^{*}$ \\
Greenland & 50 & 39 & 46 & $58^{*}$ \\
\hline
\end{tabular}

* indicates regions where the deposition increases with respect to 2000 .

their nitrogen deposition. Sulfate deposition rates are clearly projected to significantly decrease by 2100 , as expected from Fig. 5. All these confirm the results published in Lamarque et al. (2011) in a single model study using the same emission fields applied in the present study.

\section{Discussion and conclusions}

We have presented in this paper the multi-model mean annual deposition fields of nitrogen and sulfate as simulated in the Atmospheric Chemistry and Climate Model Intercomparison Project (Lamarque et al., 2013). We have made considerable use of network-based wet deposition datasets (including a new dataset based on expert analysis of the deposition data; Vet et al., 2013) and found that the ACCMIP multi-model mean performs similarly (in terms of mean bias and correlation coefficient for the annual mean) to previous multi-model analyses (Dentener et al., 2006; Sanderson et al., 2008), with the notable exception of ammonium deposition over Asia, which is considerably worse in ACCMIP due to a regridding error in the underlying emissions over the China-Mongolia region (Lamarque et al., 2010).
Table 8. Average MMM sulfur deposition $\left(\mathrm{mg}(\mathrm{S}) \mathrm{m}^{-2} \mathrm{yr}^{-1}\right)$ over specific regions as defined in Lamarque et al. (2011). The deposition does not increase in any of these regions with respect to 2000.

\begin{tabular}{lcccc}
\hline Region & 2000 & $\begin{array}{c}\text { RCP2.6 } \\
2100\end{array}$ & $\begin{array}{c}\text { RCP4.5 } \\
2100\end{array}$ & $\begin{array}{c}\text { RCP8.5 } \\
2100\end{array}$ \\
\hline Canada & 154 & 38 & 34 & 45 \\
USA & 506 & 65 & 71 & 75 \\
Mexico & 433 & 76 & 121 & 93 \\
C. America & 291 & 119 & 165 & 119 \\
Brazil & 120 & 52 & 67 & 69 \\
Rest of S. America & 163 & 90 & 116 & 112 \\
N. Africa & 145 & 48 & 96 & 67 \\
W. Africa & 133 & 103 & 115 & 126 \\
E. Africa & 123 & 73 & 89 & 97 \\
S. Africa & 157 & 148 & 79 & 133 \\
W. Europe & 534 & 98 & 141 & 107 \\
C. Europe & 1080 & 127 & 188 & 146 \\
Turkey & 727 & 136 & 205 & 130 \\
Ukraine & 794 & 80 & 129 & 98 \\
Kazakhstan area & 258 & 39 & 61 & 99 \\
Russia & 195 & 40 & 46 & 60 \\
Middle East & 313 & 54 & 73 & 155 \\
South Asia & 409 & 74 & 155 & 289 \\
Korea region & 1250 & 209 & 242 & 277 \\
East Asia & 670 & 71 & 93 & 108 \\
Southeast Asia & 416 & 132 & 162 & 182 \\
Indonesia & 390 & 292 & 270 & 249 \\
Japan & 922 & 414 & 515 & 431 \\
Oceania & 115 & 56 & 81 & 64 \\
Greenland & 42 & 21 & 18 & 25 \\
\hline
\end{tabular}

Beyond the present-day analysis, we discuss a comparison of the change in deposition rates between 1980 and 2000 (using surface wet deposition) and between 1850 and 2000 (using ice cores). Although the deposition in 2000 is rather well simulated in ACCMIP, there are considerable differences between the estimated change from 1980 to 2000 and the simulated one. This is particularly the case over the United States, where changes in anthropogenic $\mathrm{NH}_{\mathrm{x}}$ (and to a lesser extent $\mathrm{NO}_{\mathrm{x}}$ ) emissions are much smaller than over Europe, and do not lead to the observed deposition rate changes. In terms of ice core analysis, the ACCMIP multi-model mean captures many of the regional features of deposition, but there seems to be an overall overestimation of nitrogen deposition in 2000 over the Arctic, while Antarctic deposition fluxes are well simulated.

The discussion of the total deposition (wet + dry) in the ACCMIP multi-model mean confirms to a large extent the single-model results discussed in Lamarque et al. (2011). In particular, there are large regional increases in 2100 nitrogen (N) deposition in Latin America, Africa and parts of Asia under some of the scenarios considered. Increases in South Asia are especially large, and are seen in all scenarios, with 2100 values more than double 2000 in some scenarios and 
reaching region averaged values of $>1300 \mathrm{mg}(\mathrm{N}) \mathrm{m}^{-2} \mathrm{yr}^{-1}$ in RCP 2.6 and 8.5, 30-50\% larger than the values in any region currently (circa 2000). In contrast, no regions with sulfur deposition fields in 2100 larger than 2000 are identified. The multi-model mean deposition fields as discussed in this study are available at http://acd.ucar.edu/ lamar/ACCMIP/ Deposition/all_fields_062013.tar.gz.

Numerical experiments such as described in the present paper highlight regions of deposition where routine measurements are unavailable. For example, few measurements are available in South America or Africa where the projected RCP changes between 2000 and 2100 are significant increases, according the RCP projections used here. On the other hand, it is clear that the expansion of measurement capabilities highlight the necessity for a better and higher resolution representation of emissions. Finally, the analysis presented here shows that there is strong potential in using nitrogen and sulfate deposition observational data to identify gaps in our understanding of (and possibly constrain) the change in respective precursor emissions. Expansion of the WMO wet deposition assessment to earlier periods and more ice cores (especially in the vicinity of polluted areas, such as the Alps or Himalayas) can provide a window on nitrogen and sulfate emission changes, possibly helping us to understand the inability of current models to reproduce the observed long-term trends in Northern Hemisphere surface ozone (Lamarque et al., 2010).

\section{Supplementary material related to this article is \\ available online at http://www.atmos-chem-phys.net/13/ 7997/2013/acp-13-7997-2013-supplement.pdf.}


oxidation, Atmos. Chem. Phys., 3, 49-65, doi:10.5194/acp-3-492003, 2003.

Bouwman, A. F., Van Vuuren, D. P., Derwent, R. G., and Posch, M.: A global analysis of acidification and eutrophication of terrestrial ecosystems, Water Air Soil Pollut., 141, 349-382, doi:10.1023/A:1021398008726, 2002.

Butchart, S. H. M., Walpole, M., Collen, B., van Strien, A., Scharlemann, J. P. W., Almond, R. E. A., Baillie, J. E. M., Bomhard, B., Brown, C., Bruno, J., Carpenter, K. E., Carr, G. M., Chanson, J., Chenery, A. M., Csirke, J., Davidson, N. C., Dentener, F., Foster, M., Galli, A., Galloway, J. N., Genovesi, P., Gregory, R. D., Hockings, M., Kapos, V., Lamarque, J. F., Leverington, F., Loh, J., McGeoch, M. A., McRae, L., Minasyan, A., Hernández Morcillo, M., Oldfield, T. E. E., Pauly, D., Quader, S., Revenga, C., Sauer, J. R., Skolnik, B., Spear, D., StanwellSmith, D., Stuart, S. N., Symes, A., Tierney, M., Tyrrell, T. D., Vié, J., and Watson, R.: Global biodiversity: indicators of recent declines, Science, 328, 1164, doi:10.1126/science.1187512, 2010.

Cameron-Smith, P., Elliott, S., Maltrud, M., Erickson, D., and Wingenter, O.: Changes in dimethyl sulfide oceanic distribution due to climate change, Geophys. Res. Lett., 38, L07704, doi:10.1029/2011GL047069, 2011.

Charlson, R. J., Lovelock, J. E., Andreae, M. O., and Warren, S. G.: Oceanic phytoplankton, atmospheric sulphur, cloud albedo, and climate, Nature, 326, 655-665, doi:10.1038/326655a0, 1987.

Dentener, F., Drevet, J., Lamarque, J. F., Bey, I., Eickhout, B., Fiore, A. M., Hauglustaine, D., Horowitz, L. W., Krol, M., Kulshrestha, U. C., Lawrence, M., Galy-Lacaux, C., Rast, S., Shindell, D., Stevenson, D., Van Noije, T., Atherton, C., Bell, N., Bergman, D., Butler, T., Cofala, J., Collins, B., Doherty, R., Ellingsen, K., Galloway, J., Gauss, M., Montanaro, V., Muller, J. F., Pitari, G., Rodriguez, J., Sanderson, M., Solmon, F., Strahan, S., Schultz, M., Sudo, K., Szopa, S., and Wild, O.: Nitrogen and sulfur deposition on regional and global scales: a multimodel evaluation, Global Biogeochem. Cy., 20, GB4003, doi:10.1029/2005GB002672, 2006.

Fisher, J. A., Jacob, D. J., Wang, Q., Bahreini, R., Carouge, C. C., Cubison, M. J., Dibb, J. E., Diehl, T., Jimenez, J. L., Leibensperger, E. M., Lu, Z., Meinders, M. B. J., Pye, H. O. T., Quinn, P. K., Sharma, S., Streets, D. G., van Donkelaar, A., and Yantosca, R. M.: Sources, distribution, and acidity of sulfateammonium aerosol in the Arctic in winter-spring, Atmos. Environ., 45, 7301-7318, 2011.

Fowler, D., Coyle, M., Skiba, U., Sutton, M., Cape, N., Reiss, S., Sheppard, L., Jenkins, A., Galloway, J., Vitousek, P., Leech, A., Bouwman, L., Butterbach-Bahl, K., Dentener, F., Stevenson, D., Amann, M., and Voss, M.: The global nitrogen cycle in the 21 st century, Philos. T. Roy. Soc. Ser. B, 368, 1621, doi:10.1098/rstb.2013.0164, 2013.

Galloway, J. N., Townsend, A. R., Erisman, J. W., Bekund, M., Cai, Z., Freney, J. R., Martinelli, L. A., Seitzinger, S. P., and Sutton, M. A.: Transformation of the nitrogen cycle: recent trends, questions and potential solutions, Science, 320, 889-889, 2008.

Granier, C., Bessagnet, B., Bond, T., D’Angiola, A., Denier van der Gon, H., Frost, G., Heil, A., Kaiser, J., Kinne, S., Klimont, Z., Kloster, S., Lamarque, J.-F., Liousse, C., Masui, T., Meleux, F., Mieville, A., Ohara, T., Raut, J.-C., Riahi, K., Schultz, M., Smith, S., Thompson, A., van Aardenne, J., van der Werf, G., and van Vuuren, D.: Evolution of anthropogenic and biomass burning emissions of air pollutants at global and regional scales during the 1980-2010 period, Clim. Change, 109, 163-190, 2011.

Kanakidou, M., Duce, R. A., Prospero, J. M., Baker, A. R., BenitezNelson, C., Dentener, F. J., Hunter, K. A., Liss, P. S., Mahowald, N., Okin, G. S., Sarin, M., Tsigaridis, K., Uematsu, M., Zamora, L. M., and Zhu, T.: Atmospheric fluxes of organic N and $\mathrm{P}$ to the global ocean, Global Biogeochem. Cy., 26, GB3026, doi:10.1029/2011GB004277, 2012.

Keene, W. C., Galloway, J. N. and Holden, J. D.: Measurement of weak organic acidity in precipitation fem remote areas of the world, J. Geophys. Res., 88, 5122-5130, 1983.

Klimont, Z., Smith, S. J., and Cofala, J.: The last decade of global anthropogenic sulfur dioxide: 2000-2011 emissions, Environ. Res. Lett., 8, 014003, doi:10.1088/1748-9326/8/1/014003, 2013.

Lamarque, J. F., Kiehl, J. T., Brasseur, G. P., Butler, T., Cameron-Smith, P., Collins, W. D., Collins, W. J., Granier, C., Hauglustaine, D., Hess, P. G., Holland, E. A., Horowitz, L., Lawrence, M. G., McKenna, D., Merilees, P., Prather, M. J., Rasch, P. J., Rotman, D., Shindell, D., and Thornton, P.: Assessing future nitrogen deposition and carbon cycle feedback using a multimodel approach: analysis of nitrogen deposition, J. Geophys. Res., 110, D19303, doi:10.1029/2005JD005825, 2005.

Lamarque, J.-F., Bond, T. C., Eyring, V., Granier, C., Heil, A., Klimont, Z., Lee, D., Liousse, C., Mieville, A., Owen, B., Schultz, M. G., Shindell, D., Smith, S. J., Stehfest, E., Van Aardenne, J., Cooper, O. R., Kainuma, M., Mahowald, N., McConnell, J. R., Naik, V., Riahi, K., and van Vuuren, D. P.: Historical (1850-2000) gridded anthropogenic and biomass burning emissions of reactive gases and aerosols: methodology and application, Atmos. Chem. Phys., 10, 7017-7039, doi:10.5194/acp10-7017-2010, 2010.

Lamarque, J.-F., Kyle, G. P., Meinshausen, M., Riahi, K., Smith, S. J., van Vuuren, D. P., Conley, A., and Vitt, F.: Global and regional evolution of short-lived radiatively-active gases and aerosols in the Representative Concentration Pathways, Clim. Change, doi:10.1007/s10584-011-0155-0, 2011.

Lamarque, J.-F., Shindell, D. T., Josse, B., Young, P. J., Cionni, I., Eyring, V., Bergmann, D., Cameron-Smith, P., Collins, W. J., Doherty, R., Dalsoren, S., Faluvegi, G., Folberth, G., Ghan, S. J., Horowitz, L. W., Lee, Y. H., MacKenzie, I. A., Nagashima, T., Naik, V., Plummer, D., Righi, M., Rumbold, S. T., Schulz, M., Skeie, R. B., Stevenson, D. S., Strode, S., Sudo, K., Szopa, S., Voulgarakis, A., and Zeng, G.: The Atmospheric Chemistry and Climate Model Intercomparison Project (ACCMIP): overview and description of models, simulations and climate diagnostics, Geosci. Model Dev., 6, 179-206, doi:10.5194/gmd-6-179-2013, 2013.

Lee, Y. H., Lamarque, J.-F., Flanner, M. G., Jiao, C., Shindell, D. T., Berntsen, T., Bisiaux, M. M., Cao, J., Collins, W. J., Curran, M., Edwards, R., Faluvegi, G., Ghan, S., Horowitz, L. W., McConnell, J. R., Myhre, G., Nagashima, T., Naik, V., Rumbold, S. T., Skeie, R. B., Sudo, K., Takemura, T., and Thevenon, F.: Evaluation of preindustrial to present-day black carbon and its albedo forcing from ACCMIP (Atmospheric Chemistry and Climate Model Intercomparison Project), Atmos. Chem. Phys., 13, 2607-2634, doi:10.5194/acp-13-2607-2013, 2013. 
Masui, T., Matsumoto, K., Hijioka, Y., Kinoshita, T., Nozawa, T., Ishiwatari, S., Kato, E. Shukla, P. R., Yamagata, Y., and Kainuma, M.: An emission pathway for stabilization at $6 \mathrm{~W} \mathrm{~m}^{-2}$ radiative forcing, Clim. Change, 109, 59-76, doi:10.1007/s10584-011-0150-5, 2011.

McConnell, J. R. and Edwards, R.: Coal burning leaves toxic heavy metal legacy in the Arctic, P. Natl. Acad. Sci. USA, 105, 1214012144, doi:10.1073/pnas.0803564105, 2008.

Moss, R. H., Edmonds, J. A., Hibbard, K. A., Manning, M. R., Rose, S. K., van Vuuren, D. P., Carter, T. R., Emori, S., Kainuma, M., Kram, T., Meehl, G. A., Mitchell, J. F. B., Nakicenovic, N., Riahi, K., Smith, S. J., Stouffer, R. J., Thomson, A. M., Weyant, J. P., and Wilbanks, T. J.: The next generation of scenarios for climate change research and assessment, Nature, 463, 747-756, doi:10.1038/nature08823, 2010.

Murphy, D. and Fahey, D.: An estimate of the flux of stratospheric reactive nitrogen and ozone into the troposphere, J. Geophys. Res., 99, 5325-5332, doi:10.1029/93JD03558, 1994.

Opel, T., Fritzsche, D., Meyer, H., Schuett, R., Weiler, K., Ruth, U., Wilhelms, F., and Fischer, H.: 115 year ice core record from Akademii Nauk ice cap, Servernaya Zemlya: high-resolution record of Euroasian Arctic climate change, J. Glaciol., 55, 2131, 2009.

Phoenix, G. K., Hicks, W. K., Cinderby, S., Kuylenstierna, J. C. I., Stock, W. D., Dentener, F. J., Giller, K. E., Austin, A. T., Lefroy, R. D. B., Gimeno, B. S., Ashmore, M. R., and Ineson, P.: Atmospheric nitrogen deposition in world biodiversity hotspots: the need for a greater global perspective in assessing $\mathrm{N}$ deposition impacts, Glob. Change Biol., 12, 470-476, doi:10.1111/j.1365-2486.2006.01104.x, 2006.

Prather, M. J., Holmes, C. D., and Hsu, J.: Reactive greenhouse gas scenarios: systematic exploration of uncertainties and the role of atmospheric chemistry, Geophys. Res. Lett., 39, L09803, doi:10.1029/2012GL051440, 2012.

Reay, D. S., Dentener, F., Smit, P., Grace, J., and Feely, R. A.: Global nitrogen deposition and carbon sinks, Nat. Geosci., 1, 430-437, doi:10.1038/ngeo230, 2008.

Reichler, T. and Kim, J.: How well do coupled models simulate today's climate?, B. Am. Meteorol. Soc., 89, 303-311, 2008.

Rodhe, H., Dentener, F., and Schulz, M.: The global distribution of acidifying wet deposition, Environ. Sci. Technol., 36, 43824388, 2002.

Roethlisberger, R., Bigler, M., Hutterli, M., Sommer, S., Stauffer, B., Junghans, H. G., and Wagenbach, D.: Technique for continuous high-resolution analysis of trace substances in firn and ice cores, Environ. Sci. Technol., 34, 338-342, 606-607, 2000.

Sanderson, M. G., Dentener, F. J., Fiore, A. M., Cuvelier, C., Keating, T. J., Zuber, A., Atherton, C. S., Bergmann, D. J., Diehl, T., Doherty, R. M., Duncan, B. N., Hess, P., Horowitz, L. W., Jacob, D., Jonson, J.-E., Kaminski, J. W., Lupu, A., Mackenzie, I. A., Marmer, E., Montanaro, V., Park, R., Pitari, G., Prather, M. J., Pringle, K. J., Schroeder, S., Schultz, M. G., Shindell, D. T., Szopa, S., Wild, O., and Wind, P.: A multi-model source-receptor study of the hemispheric transport and deposition of oxidised nitrogen, Geophys. Res. Lett., 35, L17815, doi:10.1029/2008GL035389, 2008.

Savva, Y. and Berninger, F.: Sulphur deposition causes a large-scale growth decline in boreal forests in Eurasia, Global Biogeochem. Cy., 24, GB3002, doi:10.1029/2009GB003749, 2008.
Shindell, D. T., Lamarque, J. F., Schulz, M., Flanner, M., Jiao, C., Chin, M., Young, P., Lee, Y. H., Rotstayn, L., Milly, G., Faluvegi, G., Balkanski, Y., Collins, W. J., Conley, A. J., Dalsoren, S., Easter, R., Ghan, S., Horowitz, L., Liu, X., Myhre, G., Nagashima, T., Naik, V., Rumbold, S., Skeie, R., Sudo, K., Szopa, S., Takemura, T., Voulgarakis, A., and Yoon, J.-H.: Radiative forcing in the ACCMIP historical and future climate simulations, Atmos. Chem. Phys., 13, 2939-2974, doi:10.5194/acp13-2939-2013, 2013.

Sigl, M., McConnell, J. R., Layman, L., Maselli, O., McGwire, K., Pasteris, D., Dahl-Jensen, D., Steffensen, J. P., Edwards, R., and Mulveney, R.: A new bipolar ice core record of volcanism from WAIS Divide and NEEM and implications for climate forcing of the last 2000 years, J. Geophys. Res., 118, 1151-1169, doi:10.1029/2012JD018603, 2013.

Smith, S. J., van Aardenne, J., Klimont, Z., Andres, R. J., Volke, A., and Delgado Arias, S.: Anthropogenic sulfur dioxide emissions: 1850-2005, Atmos. Chem. Phys., 11, 1101-1116, doi:10.5194/acp-11-1101-2011, 2011.

Sutton, M. A., Oenema, O. Erisman, J. W., Leip, A., van Grinsven, H., and Winiwarter, W.: Too much of a good thing, Nature, 472, 159-161, 2011.

Taylor, K. E., Stouffer, R. J., and Meehl, G. A.: An overview of CMIP5 and the experiment design, B. Am. Meteorol. Soc., 93, 485-498, 2012.

Thornton, P. E., Doney, S. C., Lindsay, K., Moore, J. K., Mahowald, N., Randerson, J. T., Fung, I., Lamarque, J.-F., Feddema, J. J., and Lee, Y.-H.: Carbon-nitrogen interactions regulate climate-carbon cycle feedbacks: results from an atmosphereocean general circulation model, Biogeosciences, 6, 2099-2120, doi:10.5194/bg-6-2099-2009, 2009.

van Aardenne, J. A., Dentener, F. J., Klijn Goldewijk, C. G. M., Lelieveld, J., and Olivier, J. G. J.: A $1^{\circ}-1^{\circ}$ resolution dataset of historical anthropogenic trace gas emissions for the period 1890 1990, Global Biogeochem. Cy., 15, 909-928, 2001.

van Vuuren, D. P., Edmonds, J., Kainuma, M., Riahi, K., Thomson, A., Hibbard, K., Hurtt, G. C., Kram, T., Krey, V., Lamarque, J.-F., Matsui, T., Meinshausen, M., Nakicenovic, N., Smith, S. J., and Rose, S. K.: The representative concentration pathways: an overview, Clim. Change, 109, 5-31, doi:10.1007/s10584-011-0148-z, 2011.

Vet R., Artz, R., Shaw, M., Ro, C.-U., Carou, S., Aas, W., Baker, A., Bowersox, V., Dentener, F., Galy-Lacaux, C., Hou., A., Pienaar, K., Gillett, R., Forti, M. C., Gromov S., Hara, H., Khodzher, T., Mahowald, N., Nickovic, N., Rao, P. S. P., and Reid, N.: A global assessment of precipitation chemistry and deposition, Atmos. Environ., submitted, 2013.

WMO/GAW: Manual for the GAW Precipitation Chemistry Programme: Guidelines, Data Quality Objectives and Standard Operating Procedures, World Meteorological Organization/Global Atmosphere Watch, No. 160, Geneva, Switzerland, 2004.

Wolff, E. W.: Ice sheets and nitrogen, Philos. Trans. R. Soc. Ser. B 368, 1621, doi:10.1098/rstb.2013.0127, 2013.

Xie, P. and Arkin, P. A.: Global precipitation: A 17-year monthly analysis based on gauge observations, satellite estimates, and numerical model outputs, B. Am. Meteorol. Soc., 78, 2539-2558, 1997.

Xing, J., Pleim, J., Mathur, R., Pouliot, G., Hogrefe, C., Gan, C.-M., and Wei, C.: Historical gaseous and primary aerosol emissions 
in the United States from 1990-2010, Atmos. Chem. Phys. Discuss., 12, 30327-30369, doi:10.5194/acpd-12-30327-2012, 2012.

Yang, D., Kane, D., Zhang, Z. Legates, D., and Goodison, B.: Bias-corrections of long-term (1973-2004) daily precipitation data over the northern regions, Geophys. Res. Lett., 32, L19501, doi:10.1029/2005GL024057, 2005.

Young, P. J., Archibald, A. T., Bowman, K. W., Lamarque, J.-F., Naik, V., Stevenson, D. S., Tilmes, S., Voulgarakis, A., Wild, O., Bergmann, D., Cameron-Smith, P., Cionni, I., Collins, W. J., Dalsøren, S. B., Doherty, R. M., Eyring, V., Faluvegi, G., Horowitz, L. W., Josse, B., Lee, Y. H., MacKenzie, I. A., Nagashima, T., Plummer, D. A., Righi, M., Rumbold, S. T., Skeie, R. B., Shindell, D. T., Strode, S. A., Sudo, K., Szopa, S., and Zeng, G.: Pre-industrial to end 21 st century projections of tropospheric ozone from the Atmospheric Chemistry and Climate Model Intercomparison Project (ACCMIP), Atmos. Chem. Phys., 13, 2063-2090, doi:10.5194/acp-13-2063-2013, 2013.
Zaehle, S., Friedlingstein, P., and Friend, A. D. Terrestrial nitrogen feedbacks may accelerate future climate change, Geophys. Res. Lett., 37, L01401, doi:10.1029/2009GL041345, 2010.

Zhang, L., Jacob, D. J., Knipping, E. M., Kumar, N., Munger, J. W., Carouge, C. C., van Donkelaar, A., Wang, Y. X., and Chen, D.: Nitrogen deposition to the United States: distribution, sources, and processes, Atmos. Chem. Phys., 12, 4539-4554, doi:10.5194/acp-12-4539-2012, 2012. 